\title{
無茵下顎歯槽部に対する蒾槽形成に関する実験的研究
}

\author{
九州歯科大学第 1 口腔外科学教室 (指導 : 平川正輝教授) \\ 九州歯科大学口腔病理 学教室 (指導 : 上野正康教授)
}

坪根重治

（昭和46年12月22日受理）

（本論文の要旨は昭和42年 3 月30日第21回日本口腔科学会総会, 昭和42年11月 4 日第27回九州歯科学会総会, 昭 和44年 4 月26日第23回日本口腔科学会総会, 昭和44年 5 月25日第29回九州歯科学会総会に执いて発表した）

\section{EXPERIMENTAL STUDY ON ALVEOLAR PLASTIC AT THE EDENTULOUS LOWER JAW}

By

Sigeharu TSUBONE

First Department of Oral Surgery (Director: Prof. Masateru HIRAKAWA)

Department of Oral Pathology (Director: Prof. Masayasu UENO)

Kyushu Dental College, Kitakyushu, Japan

It has been said that there is a close connection between the height of alveolar ridge and the support of denture, and it cannot be denied that alveolar ridge, after extraction of teeth, has the fate of gradual atrophy, which causes the denture to be -unstable. Since the suppot and stability of lower full denture largely depends upon the form of alveolar, I should here suggest as a method of the fundamental settlement that the form of alveolar should be improved by bone grafting on the alveolar ridge.

I experimentally produced edentulous alveolar devoid of most of the alveolar bone on the lower premolars section of grown-up dogs, and made alveolar plastic on the alveolar ridge, of autogenous ribs and Kiel bone grafts as grafting material.

The results were summarized as follows.

Roentgenographic findings :

1. In the autogenous rib graft implanted group, the implanted bone and the alveolar bone could scarcely be distinguished 90 days after operation, wnile in the Kiel bone graft implanted group the network of bone trabeculae became vague but remained to be a dark pattern for 60 days to 90 after operation, and it was not till 180 days later that the distinction between them vanished completely.

2. The plastic part of bone transplanted high above the bone cavity lost the shape of its top 14 days to 21 later, while in the Kiel bone graft implanted group the bone trabeculae, which is higher than the alveolar ridge, was not observable 60 days after operation, and in the autogenous rib graft implanted group, the top of implanted bone was found a little higher than the alveolar ridge even 60 days after operation. It was 180 days later that the high plastic part vanished.

Microscopic findings : 
1. In the autogenous rib graft implanted group the development of new bone trabeculae was observed to rise from both the alveolar socket wall and the implanted bone, more vigorous than in any of the two other groups, and bony adhession took place between them on the 30th day after operation.

2. In the Kiel bone graft implanted group, the new bone from the socket wall kept filling the trabeculae of Kiel bone and then gradually the socket wall, but 90 days after operation the whole socket had not been filled yet.

3. The growth of new bone, in the early stage, is the fastest in the autogenous rib graft implanted group, and the next in the Kiel bone implanted group, and the last in the control group. The distinction would be found less than 90 days after operation, but by the 180th day, even in the control group where bone restoration is latest, the socket had been filled completely with new bone. The differences in these groups could scarcely be recognized.

4. In the early stage alveolar ridge was resorbed, but afterwards new bone began to be added; especially in the autogenous rib graft implanted group some quantity of new bone grew from the alveolar ridge towards the top of graft, serving to support the transplanted bone from sides. These findings were available till 90 days after operation.

5. Transplanted bone would be changed and reorganized into new bone, but only part of it. The Kiel bone trabeculae remained buried and scattered in the new bone even 180 days after operation.

6. There already began to appear osteoclasts on the soft tissue adjoining to the transplanted bone a week after transplantation, and in the course of absorption grew lower the top of graft. In the Kiel bone graft implanted group the plastic part above the alveolar ridge almost vanished except for part of it 60 days after operation. On the other hand, in the autogenous rib transplanted group the top of graft still was in the stage of resorption and lowering, a litlle aboue the alveolar ridge for 60 days to 90 after operation.

7. The absorption and lowering of the top of graft made gradual progress for 60 days to 90 after operation. but in the autogenous rib graft implanted group it stopped at the same period as the former, and new rows of osteoblasts were found on the absorbing surf. ace. After 180 days passed, the alveolar ridge of plastic area took a saddle-like form, increasing a little in breadth.

8. According to the findings stated above, it cannot be too nuch said that in the method of bone transplantation I experimented, alveolar plastic showed the good results till 90 days after operation, especially in the autogenous rib graft implanted group, but it eventually created only an alveolar ridge in a saddle-like form.

\section{目次}

I 緒 言

II 実験材料ならびに㥶験方法

III 実験成績

I Kiel Bone Graft 移植群
1) レ線学的所見

2 ) 病理組織学的所見

3) 小括

2 新鮮自家肺骨移植群

I）上線学的所見 
2 ) 病理組織学的所見

3）小 括

3 対照群

1）上線学的所見

2) 病理組織学的所見

3) 小括

$N$ 総括ならびに考按

$\mathrm{V}$ 結，論

V 参考文献

\section{I 緒言}

顎骨歯槽部は，㐘牙を植立支持するために構築されて いるのであるから，歯牙が变失すれば，その存在意義を 失い，その部に著しい変化が起るととは当然のととであ

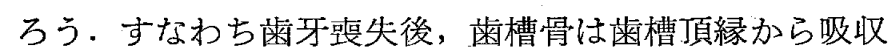
が始まり，漸次骨性䨑槽部全体の顕著な吸収萎縮を招来 する・特に下頷骨に捛いては，下顎体の約 $2 / 5$ を占める畨 槽部は, 霜牙のすへててが消失して無䨑頡になると, まず 䨑槽部の大部分が消失する.さらに骨の吸収が骨体にお よんだ場合，その吸収が強い時には，顎堤の高さは顎骨 の筋付着部附近まであ低下してしまうのである11.

従来加, 顎骨歯槽部, すなわち顎堤の高さ之義歯の 維持との間には非常に密接な関係があるととは周知の事

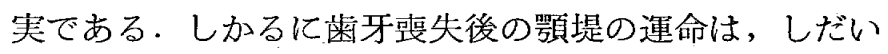
に萎縮低下してゆくのであるから，義歯不安定の方向を 辿るととは否めない事実である。このような如何ともし 難い事実があるにもかつわらず，なおかつ義蒾の維持安 定を計る日的で, 従来から種々な方法が試みられてき た。すなわち，1949年 Goldberg および Gershkoff $\mathrm{f}^{2) 3 \text { ) }}$ の報告以来, 数多くの追試が行われ, 本邦にて㸓田他 4)566)7), 河合他8）その他多くの基礎的ならびに臨床的研 究報告がみられる implant denture があり，また1953年 Lew および Kestenbaum9) によって広く一般隹紹介さ れて以来, 本邦においても, 小林10), 䀣田他11), 奥野他 12)らによって追試されてきたいわゆる button denture, あるいはまた従来からのideaを用いた magnet denture などがある.とれらの technique は, 従来義菌の維持 を腔粘膜の接着, 吸着, 粘着あるいは残存歯への釣に 求めていたのに対して，顎本体にその維持を求め，ある いは磁力によって義歯を保持したりする点に打いてより 劃期的なもので, したがって床は不要となる可能性む含 んでいるかとも想像された. しかし, てれらの方法る近 年抗生物質などの発達と外科手術の進展によって可能と なったとはいうすのの，やはり口腔粘膜と金属との接合
部からの感染や，顎の形態変化住対する金属の適応， あ るいは磁力の作用方向と咬合運動との関係の技術的困難 度, また磁力による筋疲労や顎の変形など, 長期的には かなりの障碍が考えられ，その応用にはなお慎重な考慮 を要する多くの課題が残されている。

そこで, 特に下顎総義歯の維持安定には, 歯槽の形態 が大いに関与するととから, その根本的解決法の一つと して, 歯槽堤に骨移植を行い, その形態を改善する方法 が考えられるのである.乙れに関する研究では, 村田 19)の歯槽頂部への骨・軟骨移植実験, 吉田22)の自家腸骨 移植による歯槽形成についての報告があるが，いまだ詳 細な報告はみられない。

著者は, 実験的にイヌの下頷に無歯部を作り,この粕 槽堤へ自家肋骨扎よび Kiel bone graft (以下, K骨と 略す）をそれぞれ移植した群と，骨移植を行わない対照 群之をレ線学的ならびに病理組織学的に比較検討し，い さ〉かの知見を得たので，と〉にその詳細を報告する次 第である。

\section{II 実験材料および実験方法}

生後 1 年から 2 年くらいの中型成犬を使用して, その 下顎小臼歯 4 本を連続抜去し，同時に，その部の歯槽骨 を歯根尖部付近まで除去した。そして歯槽頂を平坦に形 成した後, 約】ケ月間放置して骨移植を行った。

骨移植に際しては，まず新鮮自家肋骨移植の場合に は, 通法に従って長さ約 $2 \mathrm{~cm}$ の肋骨片を採取し, 一旦, ペニシリン加生理食塩水中に浸漬しておき，また $\mathrm{K}$ 骨移 植の場合には，市販の滅菌密封された海綿質 $\mathbf{K}$ 骨を予め 用意して移植実験を開始した。すなわち，2\%チオペン タールナトリウムの静脉内注射による全身床酔下に, ま ず下顎第 I大毛菊の㚘頁側歯肉粘膜に縦切開を加え, さら に歯肉煩移行部に沿って, 前方へ犬歯部に至る横切開を 行い，粘膜骨膜弁を剥離して歯槽骨を露出した。次に， その露出した歯槽頂に，骨ノミで移植骨片の形態に合わ せて溝状の骨創舡を形成した．との梁さ骨䯣に達する骨 創腔に，移植骨片をその上端が歯槽頂よりも高くなるよ うに，かつ移植骨片が可及的に骨創腔に適合するよう に, 移植骨片の形態扣よび大きさを整えてから㰩入移植 した.さらに自家骨移植の場合には, 骨創腔形成の際に 採取した局所自家骨小片を移植肋骨片の周囲に追加移植 した。な怙䅦骨片と母床とは, 特に線などによる結絮 固定はしなかったままた感染防止の目的で, 抗生物質を 手術創に散布し, 骨膜の横切割により減張を施した粘膜 骨膜弁を閉鎖縫合して手術を完了した（図】）．対照と 
図1。

I
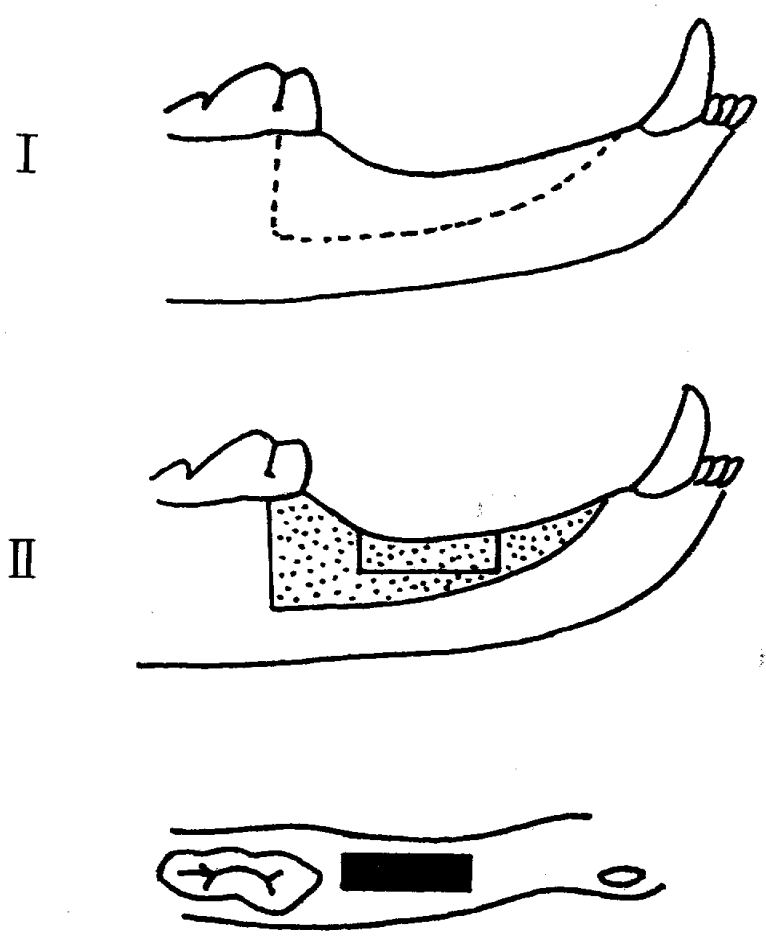

しては，骨移植の場合と同様 の骨創 腔を形成したぐけ で，骨移植を行わないすのを用意した。な捄後 $2 \sim 3$ 日間は，ペニシリン投与を行い術後感染を防止した.

移植後 7 日，14日，21日，30日，60日，90日扰よび 180日の各実験期間経過後, 動物を 全身麻 酔下に空気栓 塞により致死せしめた。実験材料は, 各移植期間毎に歯 科用 $\mathrm{X}$ 線装置によってレ線撮影を行った後, $10 \%$ ォル マリンで固定、硝酸脱灰を行いセロイヂンに包埋して, $15 \mu$ の薄切片を作製, ヘマトキシリン・エオジン重染色 を行って病理組織学的に検索した。

なお，全実験例を一覧表にまとめると，次のようにな る(表 I).

表 I 各群別症例番号一覧表

|Kiel bone移植群 $\mid$ 自家肋骨移植群 対 照 群

\begin{tabular}{|c|c|c|c|c|c|c|}
\hline 術後 & 7 号 L & 4 号 $\mathrm{L}$ & {$\left[\begin{array}{l}19 \text { 号 L } \\
24 \text { 号 }\end{array}\right.$} & $\begin{array}{l}\text { 16号 L L } \\
\text { 31总 } \mathbf{R}\end{array}$ & 31号 L & \\
\hline 14日 & 5 号 $\mathrm{L}$ & 8 号 $\mathbf{L}$ & $\begin{array}{l}20 \text { 号 } \\
22 \text { 号 L }\end{array}$ & 15号 L & 9 号 L & \\
\hline 21 日 & 4 号 $\mathbf{R}$ & 7 号 $\mathbf{R}$ & $\begin{array}{l}30 \text { 号 } \mathrm{R} \\
19 \text { 号 }\end{array}$ & $\begin{array}{l}18 \text { 㤐 L } \\
24 \text { 号 }\end{array}$ & 30 呂 L & \\
\hline 3" 日 & 5 号 $\mathbf{R}$ & & $\begin{array}{l}29 \text { 号 } \mathbf{2} \\
22 \text { 号 }\end{array}$ & 18兵 $\mathbf{R}$ & 9 号 $\mathrm{R}$ & 29号 L \\
\hline 60 日 & 12号 L & 8 号 R & $\begin{array}{l}15 \text { 号 R } \\
21 \text { 号 }\end{array}$ & $\begin{array}{l}20 \text { 号 R } \\
28 \text { 号 }\end{array}$ & II号 L & 28号 L \\
\hline 90 日 & 12号 R & 6 号 R & $\begin{array}{l}13 \text { 号 L } \\
23 \text { 号 L }\end{array}$ & $\begin{array}{l}\text { 17号 } \mathbf{L} \\
27 \text { 号 }\end{array}$ & ll号 R & 27㕿 L \\
\hline 180 日 & 13号 $\mathrm{R}$ & & $\begin{array}{l}17 \text { 号 } \mathbf{R} \\
23 \text { 号 } \mathbf{R}\end{array}$ & $\begin{array}{l}21 \text { 号 } \\
25 \text { 号 }\end{array}$ & 25 号 L & \\
\hline
\end{tabular}
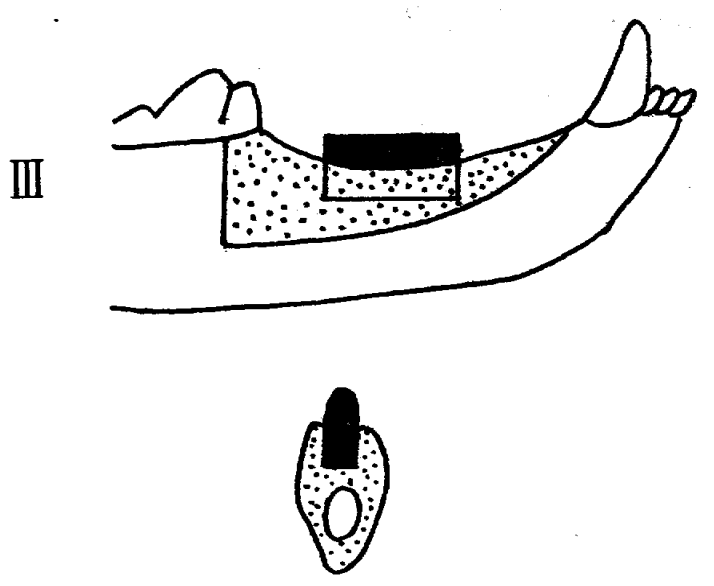

IV

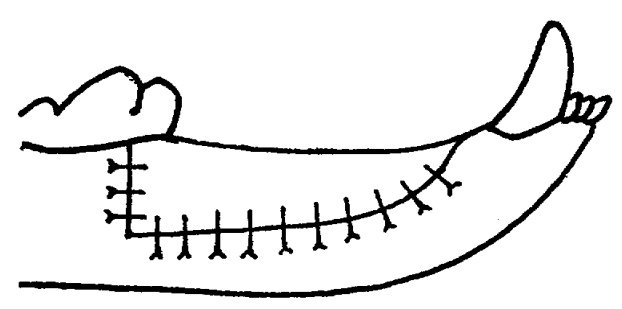

III 実 験 成 績

\section{$1 \mathrm{~K}$ 骨移植群}

1）上線所見

術後 7 日：4号 L, 7 号 $\mathrm{L}$

移植したK 骨片は，母床骨より全体的にレ線透過性は 強い，網状の骨梁が明瞭に認められ，乙の時期では，ま だ K 骨片の輪郭は明瞭で，従ってK骨と母床骨との境界 あ全く明らかである（写真 1）。

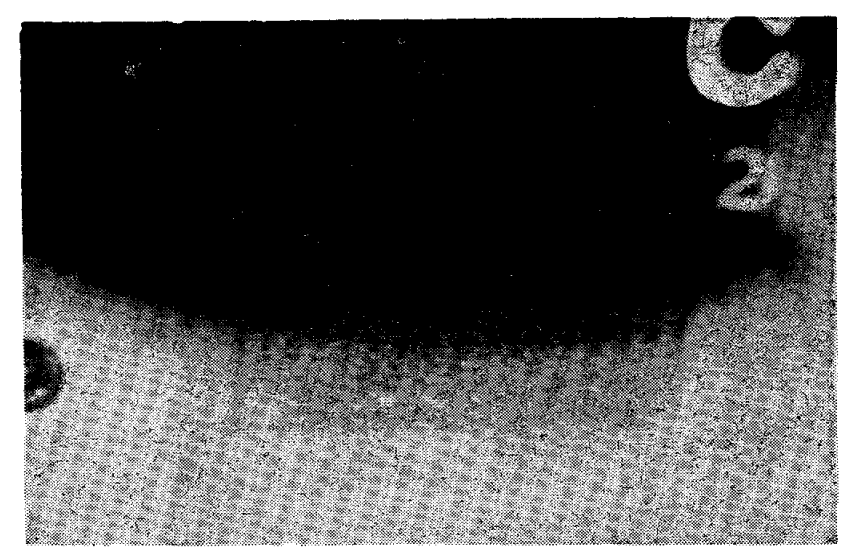

\section{写真 1 .}

術後14日：5号 L, 8 号 L

術後 7 日の所見と大差はないが，K骨と母床骨との境 界がや>不明瞭汇みえる部分も認められる（写真 2 ）。 術後21日：4号 R, 7 号 R

この時期になると，移植した $\mathrm{K}$ 骨片の上縁はや〉不明 


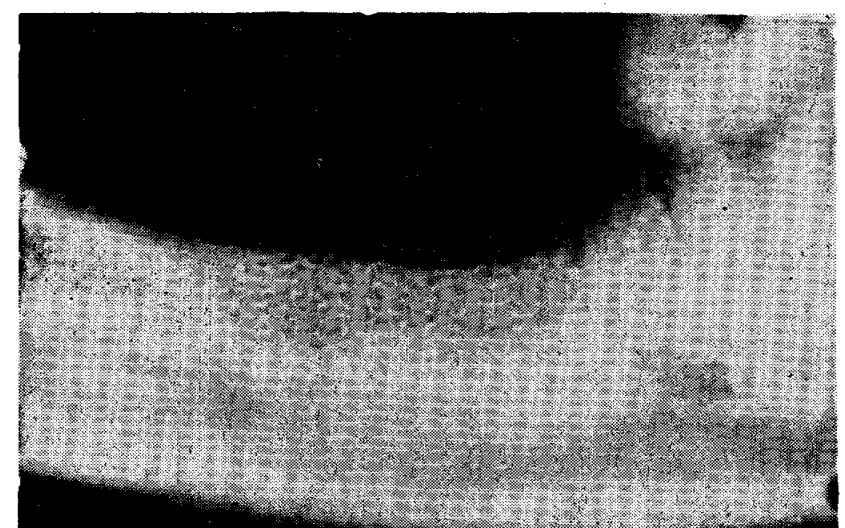

写真 2 。

瞭で，上縁に近い部分の骨梁がや〉粗になっている。ま た骨創腔底部において，K骨と母床との境界が不明暸な 部分あみられるが，他の大部分では，両者の境界は判別 できる。

術後30日： 5 号 $\mathbf{R}$

全体的にK骨片の輪郭は不明暸で, 網状の骨梁は一層 粗になってみえる. 母床この境界は不明暸になってきて いるが，K骨の像は母床よりす高く形成した部分まで, かなり明瞭に認め得る (写真 3 ).

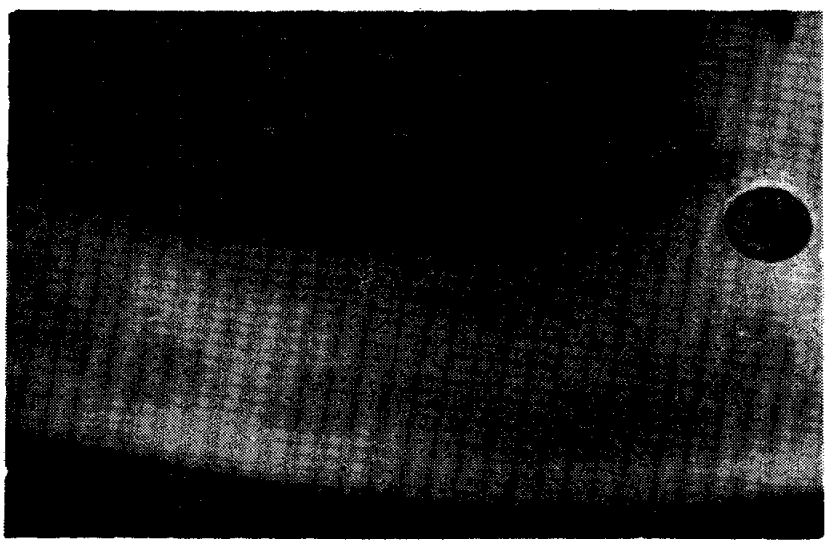

写真 3 .

術後60日：8号 R, 12号 L

術後30日までは網状の骨梁の一塊として認められた移 植 $\mathbf{K}$ 骨の像は，乙の時期になると判別できずに，移植部 が周囲母床骨よりも少し暗影像として認められるにすぎ ず，その骨梁は認め難い。したがって移植部の境界は不 明瞭で, 自然に移行してみえる.母床より高く形成した 部分のK骨の骨梁はみられない（写真 4).

術後90日：6号 $\mathbf{R} ， 12$ 号 $\mathbf{R}$

術後60日亡ほડ゙同様の所見である。

術後180日：13号 $\mathbf{R}$

この時期になると, 移植部は周囲母休骨とまったく区

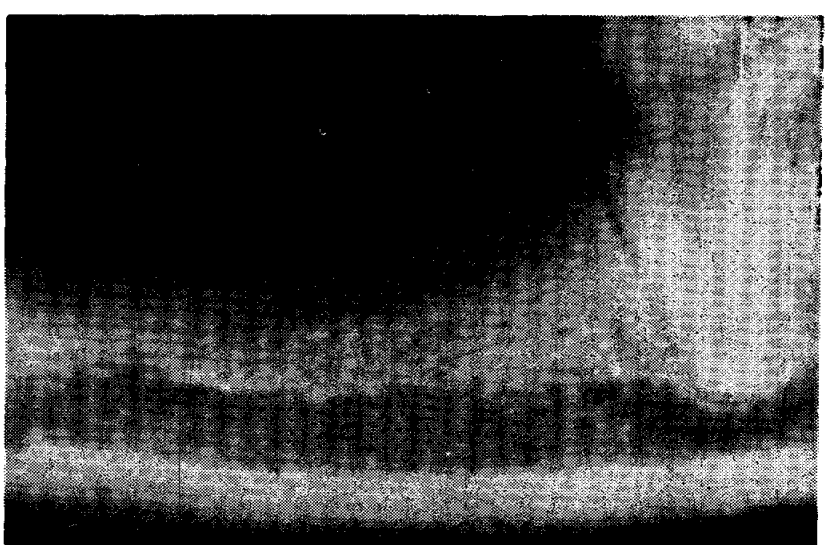

写真 4 .

別ができない．また母床より高く形成した部分の $\mathrm{K}$ 骨 あ,まったく消失してしまっている（写真 5 ）。

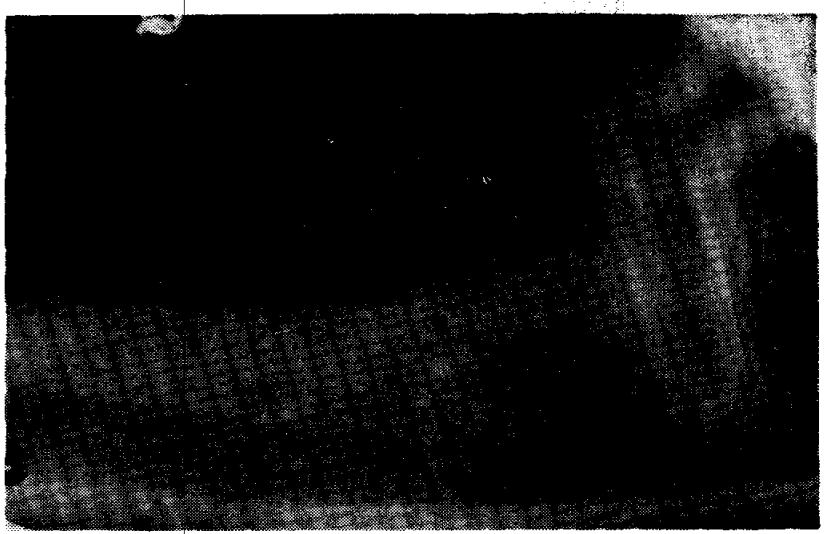

写真 5 .

2) 病理組織所見

術後7日：7号 $\mathrm{L}, 4$ 号 $\mathrm{L}$

7 号 L ; 歯肉部は充血状態で, 出血と中等度の炎症像 を認めるが，粘膜上皮は正常である，移植部直上におい て, 粘膜上皮の多少の肥厚がある. 粘膜上皮乳頭は舌側 では鋸歯状に割合整然としているが，頬側ではその大き さも間隔も大きい，雬肉と雪槽骨とは密着しており，歯 肉組織は全体的にや〉厚い。

下顎管は正常な形態を保った脂肪骨䯣である，骨創腔 内に打ける新生骨梁の添加は, 上方部においても少量な がら認められるが, 底部および側壁下方部においてより 明瞭にみられ，それは大体に打いて，下方 $1 / 3$ (舌側) か ら1/2 (煩側) くらいである (写真 6) . この母床からの 新生骨梁は，近くにあるK骨の骨梁を包みこんで，K骨 の骨梁に密着している.しかし，大部分のK骨の骨梁 は，いまだ肉芽組織中に遊離していて，これらの遊離し ている K 骨の骨梁の周囲には, 部位によっては吸収細胞 の出現がみられる. 


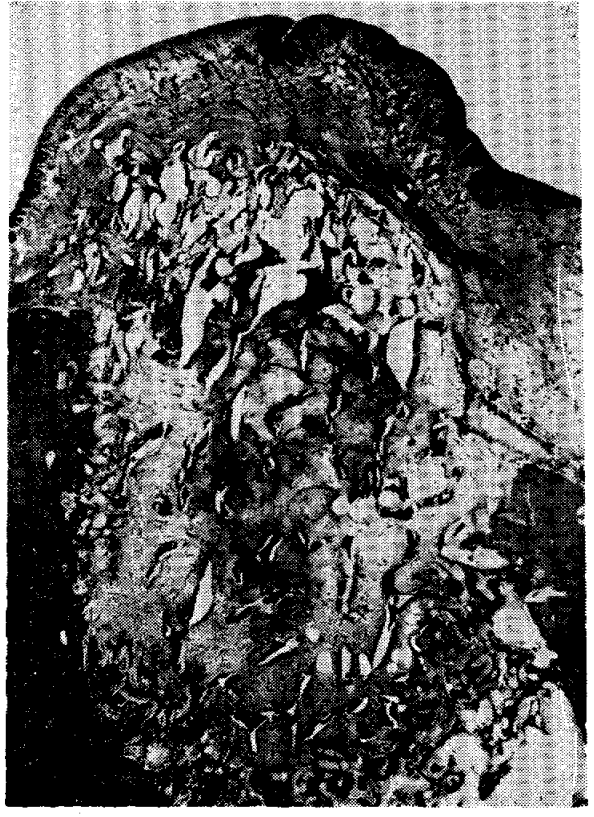

写真 6.

骨創控内の新生肉芽組織は, その形成の多い所ほど骨 梁の新生す進行している．すなわち，新生骨梁の添加の 多い骨創腔底部に扣いて肉芽組織が多く，側壁に沿って 骨創腔の上方に行くにしたがって少くなっている，ての 肉芽組織の新生は，骨創腔内からばかりでなく歯肉の， 方からあ起っている。そして，いまだ肉芽組織になって いない骨創腔の中央部では，線維素網の形成と新生毛細 血管が豊富にみられ，さらにその外側は血餅に移行して いる。

4 号 L ; 茵肉部には，7号Lの所見と同様に中等度の 炎症像がみられる。

$\mathrm{K}$ 骨片を嵌入移植した母床の骨創腔底部では，下顎管 への穿孔がみられ, その穿孔部には軽度の炎症性細胞浸 潤のある肉芽組織が形成され，また新生骨梁の添加もみ られる。

骨創腔内における新生骨梁の添加の状態および骨創腔 内に抢けるその他の病理組織所見は， 7 号 L の所見之同 様である。

術後14日：5号 L, 8 号 L

5 号 $\mathbf{L}$; 歯肉粘膜上皮は移植部直上で肥厚している。 炎症所見はあまり認められない。

骨創腔の底部では，下顎管への穿孔がみられ，下顎管 壁に沿って肉芽組織の増殖亡, 新生骨梁の添加がみられ る.

骨創腔内にお打る新生骨梁の添加は, 術後 7 日目より も進行していて，附近の $\mathrm{K}$ 骨の骨梁を包みてんでいる所 見がみられる．また新生骨梁の染色性す母床に類似した
色調となり，石灰化の進んだ状態がみられる。しかし， 一方では K 骨の骨梁の吸収所見むみられるが, 術後 7 日 目でみられた肉芽組織中に遊離している $\mathrm{K}$ 骨の骨梁の周 囲の吸収像は少くなっている。

移植した $\mathrm{K}$ 骨片は，全体的には移植時の形態をほぶ保 っており，母床より高く形成した部分む，吸収による低 下はまだそれほご顕著ではない。

新生骨梁の添加は，骨創腔内ばかりでなく，骨創空外 （母床の歯槽頂）に扑てて明膫に認められる。 そのた め母床の歯槽頂は移植前上りも僅か比高くなっている( 写真 7).

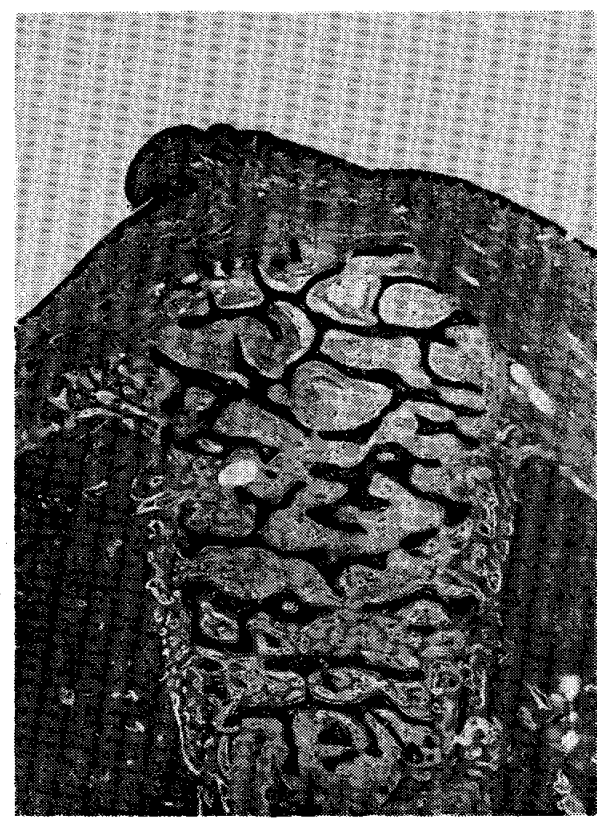

写真 7 .

移植した $\mathrm{K}$ 骨の骨梁の間を埋める部分は非常に幼若な 肉芽組織で, 新生毛細血管や線維芽細胞が豊富にみられ る。

$\mathrm{K}$ 骨の骨梁と幼若な肉芽組織との間に吵間がみられる 所があるが，その中には赤血球や漿液梯物質をいれてい る.しかし，幼若な肉芽組織が少しく陳旧になった結合 織の部分では，との $\mathrm{K}$ 骨の骨梁との間の隙間は少くなっ ている。この所見を場所的にいえば，骨創腔の上方に行 くほど隙間が多くみられるといえる。

8 号 $\mathrm{L}$; 雨肉粘膜上皮の肥厚は少いが，上皮乳頭の大 きさ抢よび形状は小さく，かつ不規則になっている。㐘 肉粘膜が母床の㐘槽頂に接する部分に炎症がや〉強くみ られるが，全般的には，蒾肉粘膜の炎症所見は軽度であ る。

骨創腔の底部では， 5 号 $\mathbf{L}$ 亡同様に下顎管に穿孔して いるが，穿孔部分が狭い所では，新生骨梁の添加によっ 
て穿孔部は塞がっていて，下顎管には割合綺麗な脂肪骨 䯣がそのま〉残っている。

移植したK骨の骨梁は，5号 Lの場合よりも散在性で ある。乙れらのK骨の骨梁に抢ける吸収所見は，母床加 らの新生骨梁の添加が旺盛な所の近くで多くみられるよ うである. また骨創腔内の $\mathbf{K}$ 骨の同一骨梁で, その同じ 骨梁の一面に吸収，他面に骨の添加がみられるあのああ る.

移植した K 骨片の母床より高く形成した部分は，5号 L と同様，まだ顕著な低下は認められない。

術後21日：4号 R，7号 R

4 号 $\mathbf{R}$; 歯肉粘膜上皮の肥厚は少く, 上皮乳頭の形, 大きさとあ不規則である。歯肉組織の厚みは７日目およ び14日目之ほメ゙同様である.

全般的炎症所見はほとんどみられない。

母床の下顎管は骨創腔の底部から穿孔されていて，そ の大部分が肉芽組織でみたされている，移植した $\mathrm{K}$ 骨の 学梁は散在してみられ，母床よりも高く形成した部分は や〉低下しているが，まだ母床よりは高く保たれてい る。

骨創㤎内における新生骨梁は, 底部や側壁近くの $\mathrm{K}$ 省 の骨梁を埋めこんでいるが，骨創腔の中央部や上方部に は，まだ遊離したま〉の $\mathrm{K}$ 骨の骨梁がみられ（写真 8 ），しかむ，それらの骨梁の周团には吸収像がみられ る.

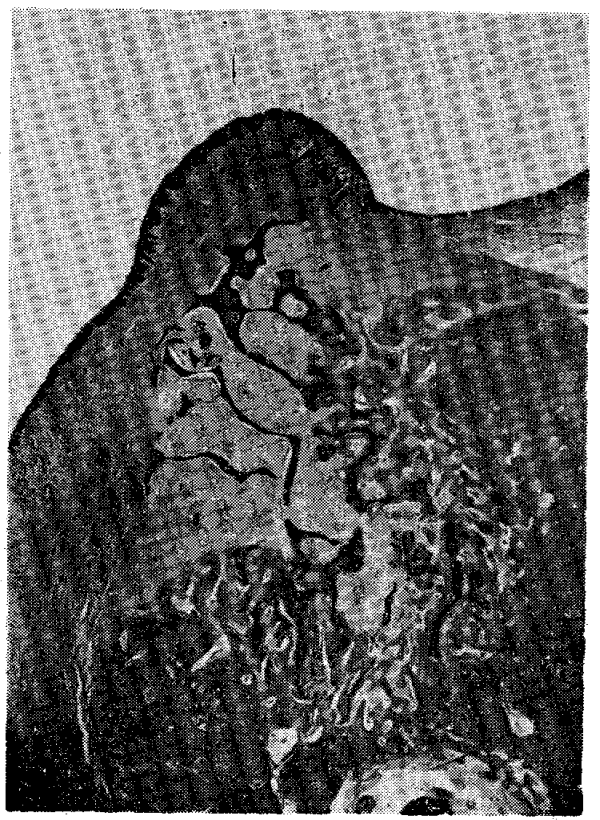

写真 8.

新生骨梁の石灰化は，母床に近接した部位ではかなり 強く, また新生骨梁間の肉芽組織は骨骬迶に变りつ〉おっ
て母床との区別はつけ難くなっている.しかし，埋めこ まれたK骨の骨梁とは明瞭に区别できる。

新生骨梁の添加は骨創腔内のみでなく，母床の㚘頁側霆 槽頂においても明瞭に認められ（写真 9 ），また少量な がら舌側蒾槽頂でもみられる.

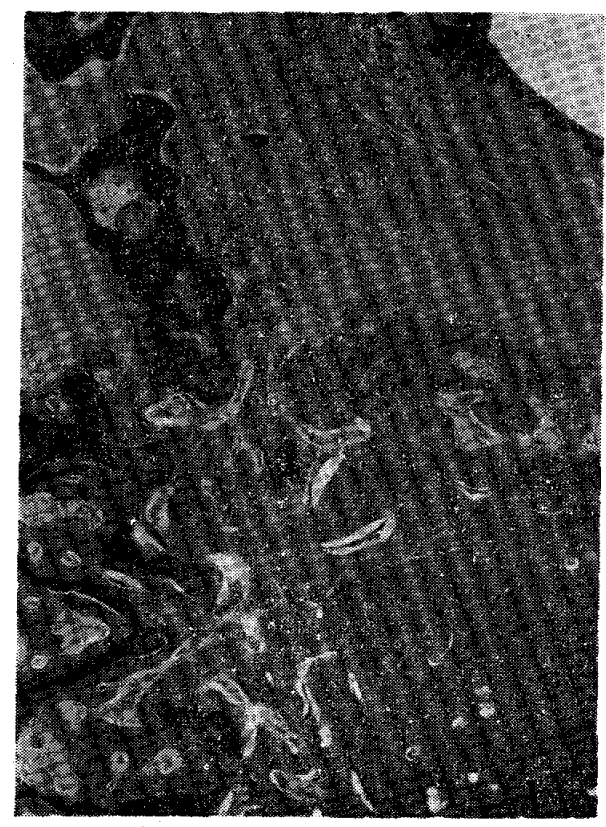

写真 9. 写真 8 の拡大

軟組織中に遊離している $\mathrm{K}$ 骨の骨梁の吸収は, 新生骨 梁に近い所にあるむのほど強く，また吸収が起っている K骨の骨梁では，同一骨梁の下面に強くみられる。

7 号 $\mathrm{R}$; 歯肉粘膜上皮の肥厚がみられ，粘膜下結合組 織に軽度の炎症所見がみられる。

K 骨片を移植した骨創控の底部は，4 号 Rでは下顎管 に穿孔したま〉の状態がみられたが，本実験例では旺盛 な新生骨梁の添加によって索状に連って, 骨創空底部に 骨の一層を形成して下顎管と骨創腔とは全く隔てられて いる。しかも，その新生骨梁の問には骨䯣むできてい る。

移植した $\mathrm{K}$ 骨の骨梁は， 4 号 $\mathrm{R}$ の所見よりも吸収状態 が強く, より一層散在性である。しかも, 一旦添加した 新生骨梁にあ吸収所見がみられる。また骨創腔外にある K骨の骨梁にむ吸収所見がみられ，乙の骨創腔外に高く 形成した部分はかなり低下しているが，母床よりは高く 保たれている。

術後30日： 5 号 $\mathbf{R}$ 1

夹肉粘膜は肥厚しているが，粘膜下結合組織に焱症所 見はみられない。

K 骨片を嵌入した骨創腔の底部で，骨創堙加占下顎管 に通じる細い穿孔があり，之の部分の不賏管壁代は，わ 
ずかに肉芽組織の増殖がみられるが，下顎管の大部分は 正常な脂肪骨髄組織でみたされている。

母床から添加した新生骨梁は，K骨の骨梁を埋めてみ ながら増殖して，骨創空内の大部分を埋めている。しか し，まだ骨創腔全体には及んでおらず，歯槽頂に扔いて 近遠心的な溝状の旧みを残している（写真10）。新生骨 梁の間の軟組織中には拡張した血管がみられ，骨䯣にな りつ〉ある所見がみられる，母床と新生骨梁とは，乙の 時期ではまだ区別できるが，骨創腔の底部では，新生骨 は層板状構造を呈した正常な骨質に近い構造を示してい る（写真11）．新生骨梁辺縁には造骨細胞がみられ，ま た移植部の母床の歯槽頂にも少量の 骨の添加がみられ る.

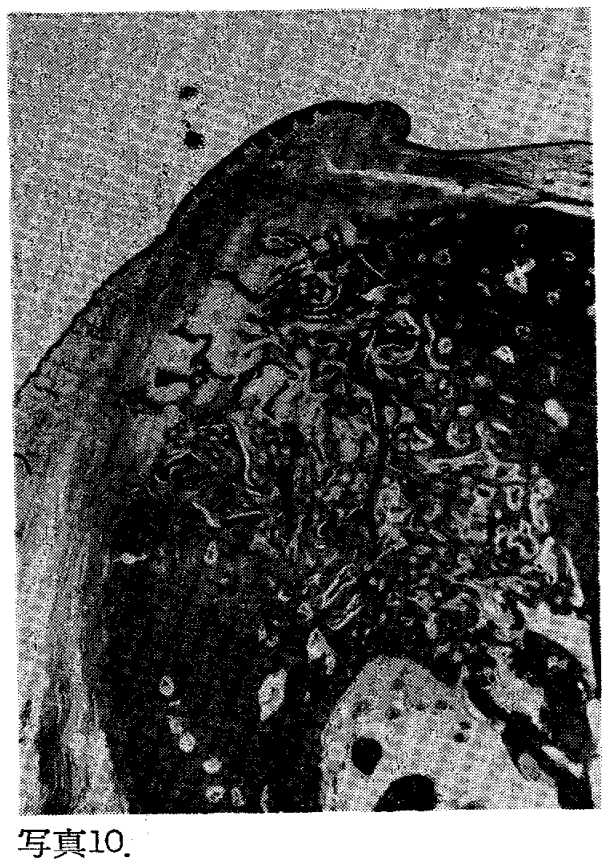

骨創腔内で新生骨梁によ二て埋めてまれた K 骨の骨梁 の一部に染色性の低下しているものがみられる。

母床より高く形成した部分の $\mathrm{K}$ 骨の骨梁は吸収されて 少し消失しているが，まだ母床よりは高い，しかし，そ の部分の $\mathrm{K}$ 骨の骨梁は軟組 織中に散在性に遊離してい て, しかも，それらの骨梁の周囲で吸収像がみられるも のがある。

$\mathbf{K}$ 骨の骨梁の分布状態をみると，早期に新生骨梁で埋 めてまれた部分では多く残っており，骨創腔の中央部で は少くなっている。

術後60日：12号 L，8号 R

12 号 L ; 歯肉粘膜上皮の肥厚はなく，移植部全般にわ たって炎症所見もみられない。

母床の下顎管壁に沿って新生骨梁の添加がみられる.

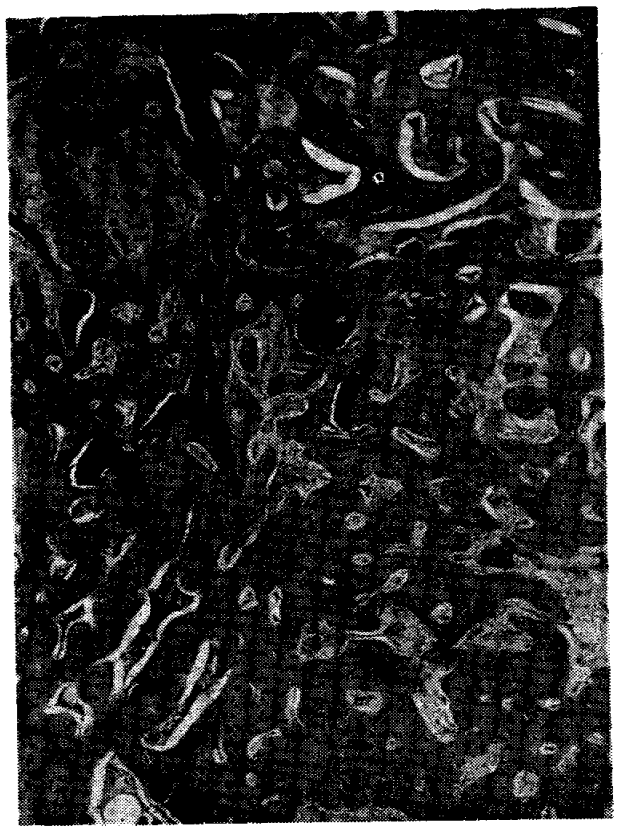

写真11. 写真100拡大

新生骨梁は骨創腔の大部分を埋めて増殖しており，そ の辺縁には造骨細胞の配列がみられるが，いまだに中央 部で降凹していて，さらにその上方には軟組織中に遊離 しているK骨の骨梁が散在している（写真12）。

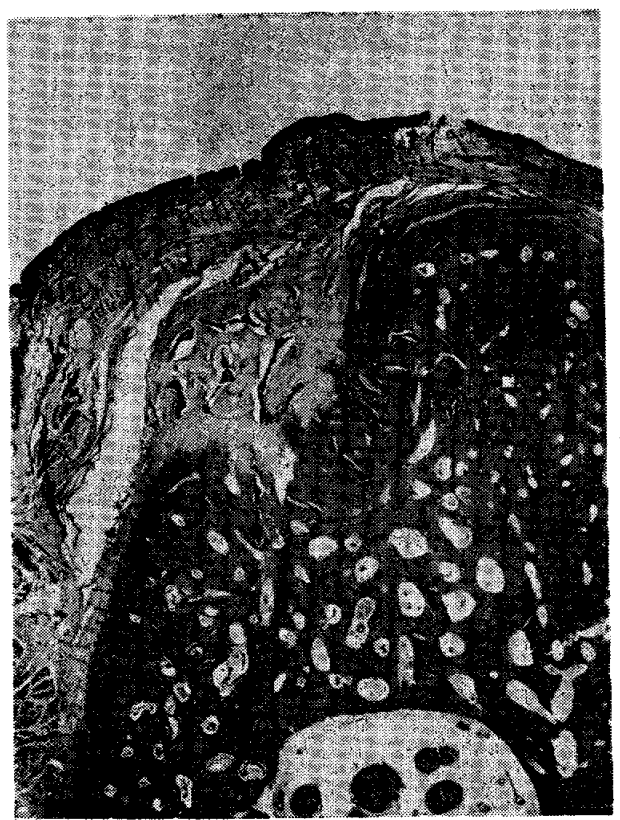

写真12.

この骨創腔を埋めた新生骨と母床との区別は困難であ る. 新生骨梁中に埋めこまれた K 骨の骨梁は，明らかに K骨として認められるあのと，またてれをとり国む周囲 骨とあまり変らないように改造されているあのとがみら れる。

新生骨梁の間の軟組織は, 骨䯣様の所見を示す所と, 
また早期に新生骨梁によって埋めてまれた所では，すで に骨髄になっている所とがある。

8 号 R；骨創腔から下顎管へ通じる交通孔がみられ， 下顎管の中へ落ちこんだ $\mathrm{K}$ 骨の骨梁が認められる．そし て, このK骨の骨梁の周团には肉芽組織の増殖がみられ る.

骨創腔内における新生骨梁の増殖の状態は 12 号 L の所 見とほ心゙同様であるが，新生骨の改造は12号Lの場合よ りあ遅れている。

移植した $\mathrm{K}$ 骨の骨梁の状態は，部位によってはや〉異 る所むあるが，打〉む敉12号Lの場合と同様である。

術後90日：12号 R，6号 R

$12 \mathbf{R}$; 菌肉粘膜上皮は平滑で, 粘膜下結合組織に炎症 所見はみられない。

母床の下顎管および骨䯣は正常である。

骨創腔内に抢ける新生骨梁の添加は，60日目の所見よ りもさらに進行して骨創舷を埋めているが，その辺縁は 局部的には不規則な陷凹を示している（写真13，14）。 また新生骨の改造むさらに進行して，母床との区別は全 く不明膫で，骨梁間の軟組織はお〉むね骨䯣に変ってい るが，一部には肉芽組織のま>の所もみられる.

新生骨梁の辺縁には造骨細胞の配列がみられるが，骨 梁間の軟組織に接する面には吸収 細胞を認める所もあ る.

新生骨梁中に埋入された K 骨の骨梁は散在性に明瞭に 認められるが，染色性が少し低下しているものあある( 写真13）。また骨創腔外の軟組織中に遊離していた $\mathrm{K}$ 骨

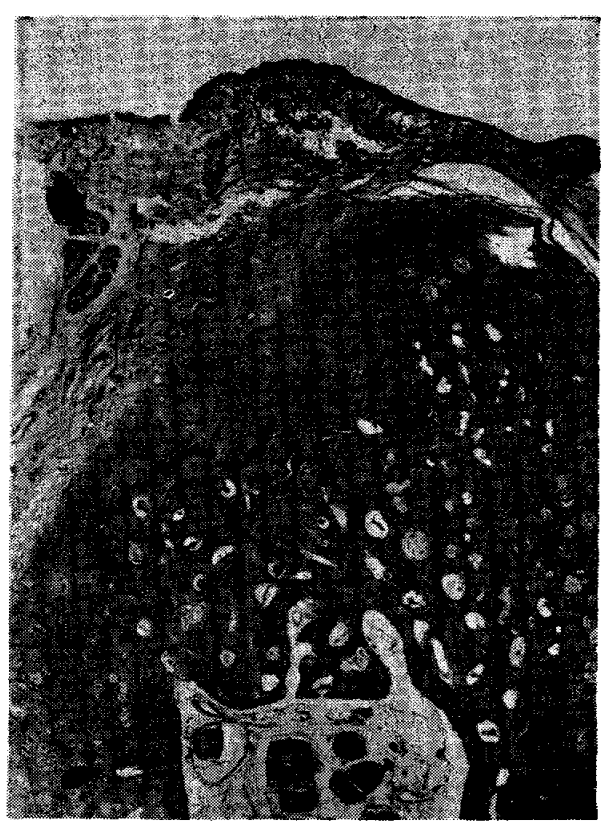

写真13.
の骨梁は,一部を除いては，ほとんどみられなくなって いる.

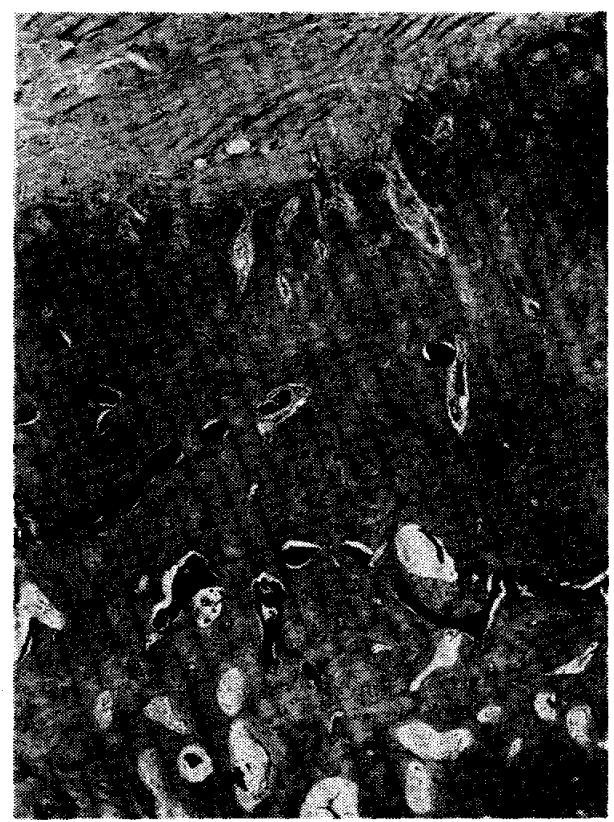

写真14. 写真130拡大

6 号 R；骨創䩗を埋めた新生骨梁は，まだもとの高さ まで回復していず，その辺縁は陥凹しているが，辺縁に は造骨細胞の配列がみられ, さかんに骨の添加増殖が行 われている.

新生骨と母床とは 22 号 R の場合之同様に全く区別がつ かない。

新生骨梁間の骨髄面に吸収細胞がみられるととは12号 $\mathrm{R}$ の所見と同様であるが，さらに本実験例では，新生骨 梁中に散在性に埋入されているK 骨の骨梁辺縁でも吸収 所見が認められる.

全般的に, 新生骨の改造は 12 号 R の場合よりも遅れて いる.

術後180日：13号 R

䨑肉粘膜上皮は，移植部直上で肥厚している.

歯槽骨を被㠅する蒾肉組織の厚さは比較的薄い.

母床の下顎管には正常な脂肪骨䯣がみられるが, 下顎 管壁に沿って新生骨梁の添加がみられる所がある.

新生骨梁は骨創腔を完全に埋め, さらに歯槽頂の形態 は移植前よりも丸味を帯びた外形を示している（写真15 ）が，その表層は全く滑かでなくて，不規則な小さな凹 凹が所々にみられる：乙媇生骨は 層板構 造を形成し て，ほとんど正常な骨質になって母床との区別は全くつ けられない，そして，その最表層部は維密骨に変りつ> あって層板状になっており, 吸収像は全く認められず, また90日目までにみられた造骨細胞の配列むすでにみら 
れない（写真16）。新生骨中の骨髄壁における吸収所見 あ，乙の時期では全く認められない。しかし，乙の時期 になっても，なお新生骨中には $\mathrm{K}$ 骨の骨梁が散在してみ られるが，その染色性はかなり低下している（写真15， 16).

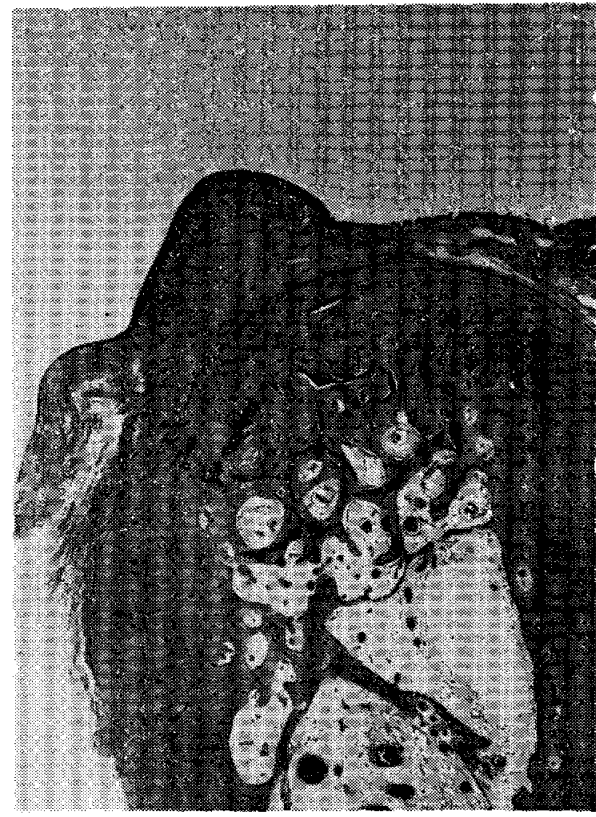

写真15.

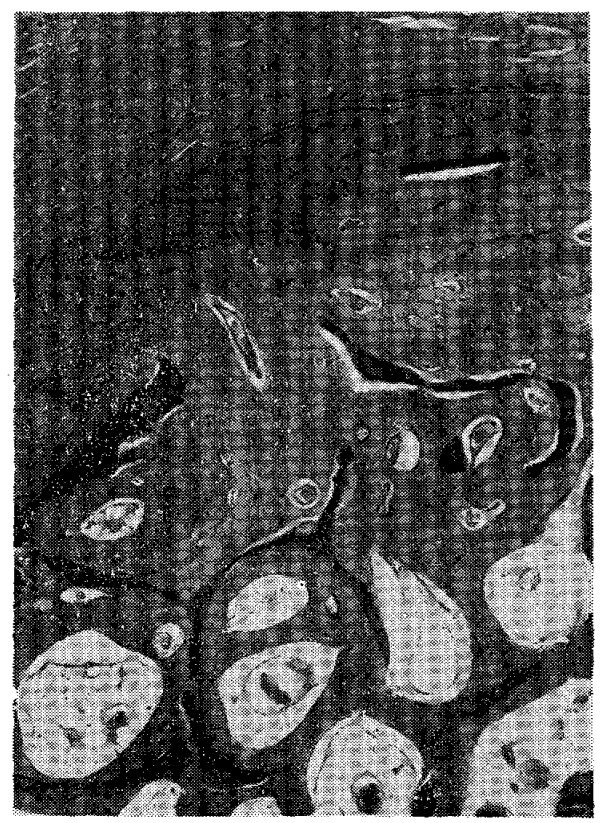

写真16. 写真150拡大

3）小括

無歯下颚㐘槽部に形成した骨創腔内に括ける新生骨梁 の添加は, 術後 7 日で,すでに底部扔よび側壁の下方 $1 / 3$ でタられ，付近のK骨の骨梁を埋め込んでいる。しか し，骨創空の大部分を埋めている肉芽組織中にある $\mathrm{K}$ 骨
の骨梁の周冊には，所々に吸収細胞が散見される．14日 目になると，新生骨梁の添加増殖はすとし進行して，骨 創腔の側壁の上縁近くまでみられるようになり，底部で 早期に添加した新生骨梁の染色性は母床のそれに類似し てくる．しかし，乙の時期になると新生骨梁の辺縁で吸 収細胞の出現もみられるようになる。

移植した $\mathrm{K}$ 骨片の形態は，まだ移植時の外形をほ心゙保 っており，移植骨頂の吸収”低下はあまりないようであ る.しかし7 日目之同様に，K骨の骨梁の周囲では吸収 が進行している.

術後21日を経過すると, 新生骨梁の添加はさらに進行 して，母床の歯槽頂に打いても認められるようになる。 骨創腔内の早期に添加した新生骨梁では石㶮化が進行し て，母床との区別がしだいに不明瞭になってくる．しか し，骨創腔の中央部扔よび上方部では，な扔幼若な肉芽 組織中にK 骨の骨梁が散在性に遊離して抢り，それらの 周囲では吸収が行われている，てのK骨の骨梁周囲での 吸収所見は，大体において新生骨梁に近い所にあるすの に多くみられるが，この時期では骨創腔外にあるものに あみられるようになり，移植骨頂はかなり低下してく る. レ線所見に扮いても，移植骨頂は不明瞭になってい て，吸収が進行していることを示している。そして， 30日目に至ると，新生骨梁は骨創腔の大部分を理めるよ うになるが，な招その辺縁では陷凹がみられる．新生骨 梁の間には骨䯣様の組織ができており，骨創腔の底部で は正常な骨質に近くなっているが，なお母床との区別は できるままた新生骨梁中に埋めこまれた K骨の骨梁の染 色性す低下している．移植骨頂は吸収されて低下してい るが，まだかなりの高さを保っている。

術後60日を経過しても，まだ骨創腔を埋める新生骨の 辺縁では陷凹がみられるが，新生骨梁の間には骨䯣ある いは骨髄様の組織ができて扣り，母床との区別が不明膫 になってきている，骨創腔外の軟組織中には，まだ $\mathrm{K}$ 骨 の骨梁が散在しているが, レ線所見では, 母床の歯槽頂 より上方にはすでにK 骨の像は認め難い。

90日目になると，新生骨梁は骨創空の大部分を埋め て，その辺縁にはなお造骨細胞が配列している，骨質の 改造も進行して母床之の区別が困難になっている. 新生 骨梁の間には，上方の一部を除いて，大体骨䯣ができて いるが，その内部に吸収細胞をみるとともある。

骨創腔外に遊離していたK骨の骨梁はこの時期に至る とほとんどみられなくなる。

そして 180 日を経過すると, 新生骨梁は骨創腔を完全 そ埋めて, しかもほとんど正常な骨質構造を示して, 母 
床との区別は全く困難になってしまう。新生骨辺縁にお ける骨の添加あるいは吸収所見は全くみられず, 緻密層 を形成している，乙線所見においても移植骨の像は全く 不明瞭で, 移植部は移植前に比へててまり変化はみられ ないような状態を示している.

しかし，ての時期になってあ，なお新生骨中にはK骨 の骨梁が散在しているが, その染色性はかなり低下して いる。

2 新鮮自家肋骨移植群

1）上線所見

術後 7日：16号 L，19号 L，24号 L，31号 R

レ線所見では，まだ移植骨にはほとんど変化はみられ ず，母床の骨創腔の輪郭も明瞭に認められる。したがっ て，母床と移植骨との境界は明瞭である（写真17）。

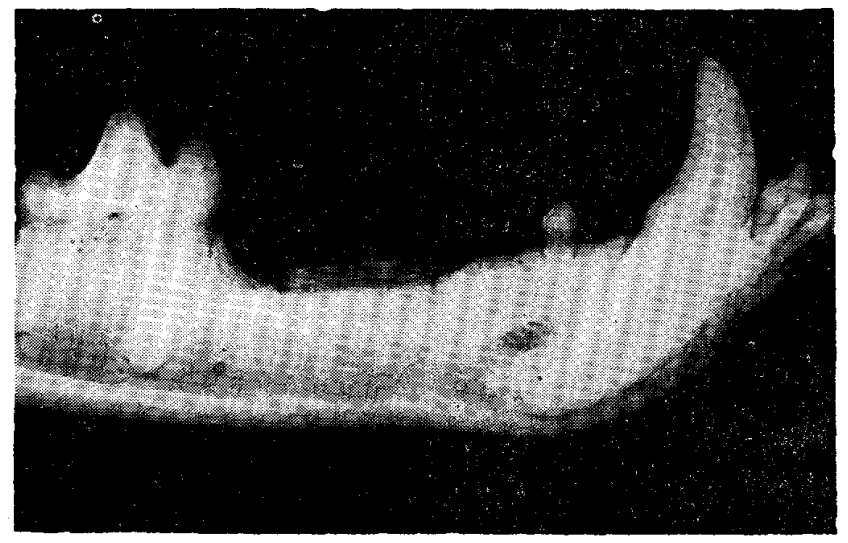

写真17.

術後14日：15号 L，20号 L，22号 L

移植冎頂は，その輪郭が部分的に凹凸を示して，移植 骨頂において吸収が起っていることが推察できる、移植 骨之母床之の境界は，一部でや〉不明瞭な部分もある が，全体的にはまだ割合明瞭に区別できる（写真18）。

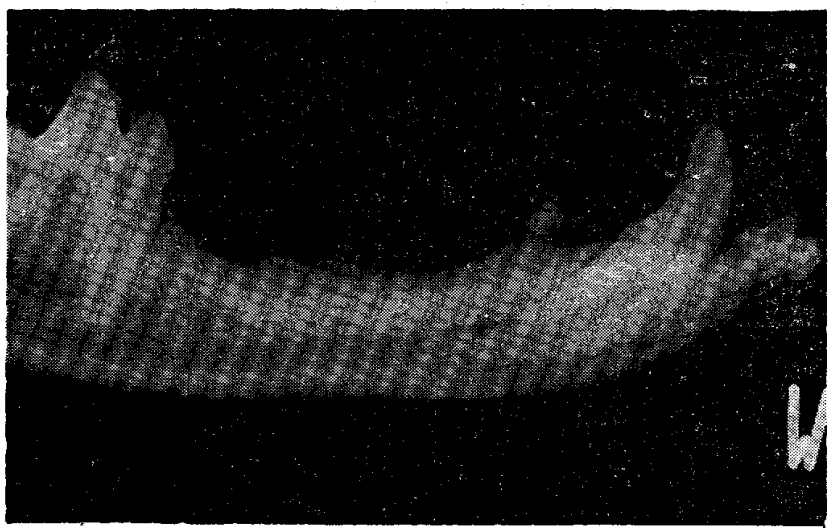

写真18.

術後21日：18号 L，19号 R，24号 R，30号 R
移植部は全体的にレ線透過性が強くなって，移植骨の 骨梁の紋様が不明瞭になっている，移植骨頂は凹むが強 くなっている．移植骨と母床との境界はかなり不明瞭に なってきているが，まだ区別はできる（写真19）。

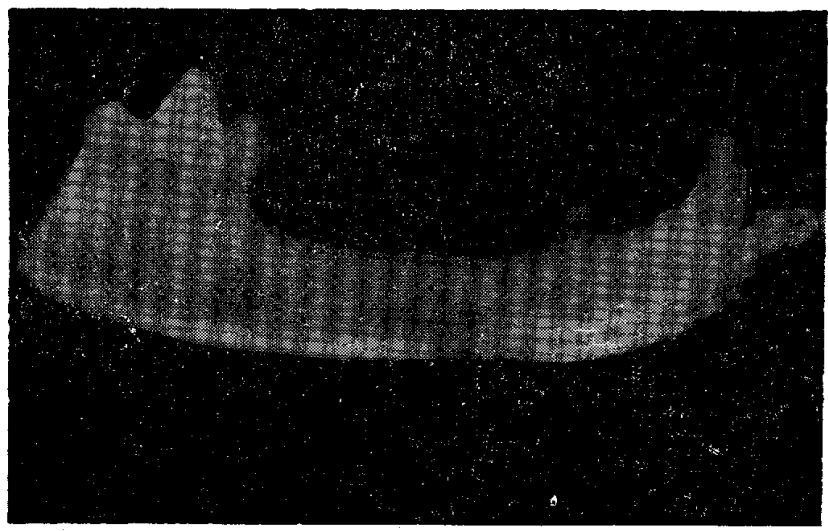

写真19

術後30日：16号 R，18号 R，22号 R，29号 R

全体的には，術後21日の所見と顕著な相違はないが， 移植骨頂における凹凹が一層強くなっていて，吸収の進 行が何われる. しかし，一方では母床との境界が漠然己 していることから, 骨創腔内での両者の瘉合が進行して いることが推察できる（写真20）。

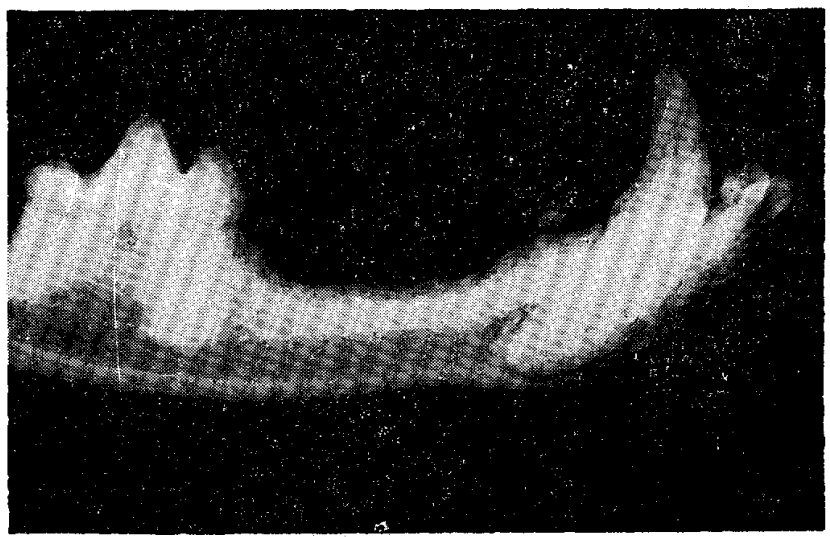

写真20.

術後60日：15号 $\mathbf{R} ， 20$ 号 $\mathrm{R} ， 21$ 号 $\mathrm{L} ， 28$ 号 $\mathbf{R}$

移植部の歯槽頂は周囲の母床の歯槽頂よりも少し高く なっているが，移植贯と母床とは，ほとんど区别ができ なくなっている、移植骨の骨梁の紋様も不明瞭になって いる(写真21).

術後90日：13号 L，17号 L，23号 L，27号 R

移植骨亡母床との判別は困難で，両者の骨性癒合之骨 の改造が進行しているととを示している，しかし，いま だに移植骨の骨梁の紋様は不明瞭である。27号 Rのレ線 写真では，母床の歯槽頂より高い位置に移植骨が認め心。 


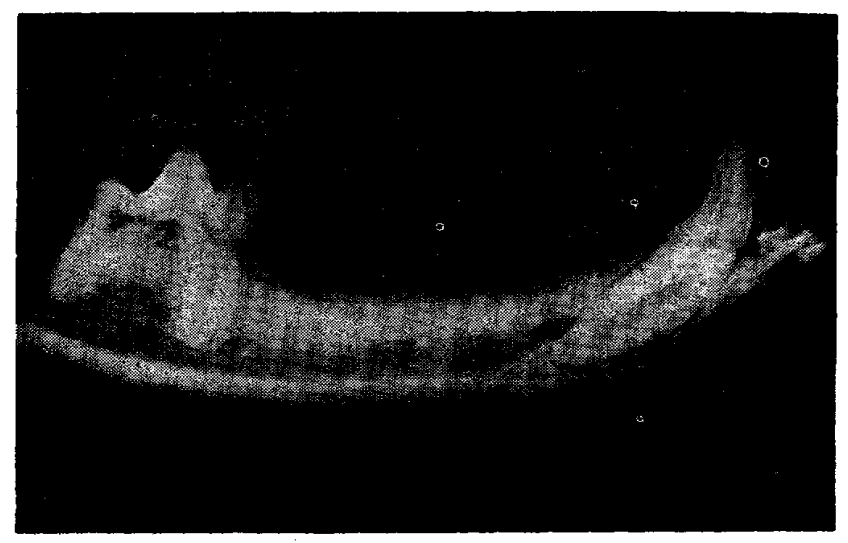

写真21.

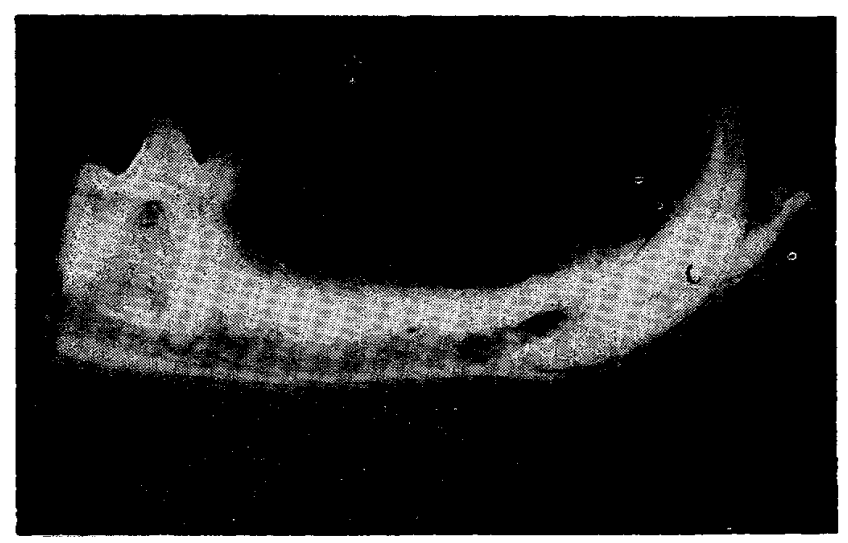

写真22.

れる（写真22）。また17号 L および23号 Lです，歯槽頂 の高まりがみられる.

術後180日：17号 R，21号 R，23号 R，25号 R

移植骨之母床との判別はほとんど不明であるが，わづ かに骨梁の走行状態が異っている．23号 $\mathbf{R}$ 抢よび25号 $\mathbf{R}$ では, 移植部歯槽頂がかなり高くなってみえる（写真 23) .

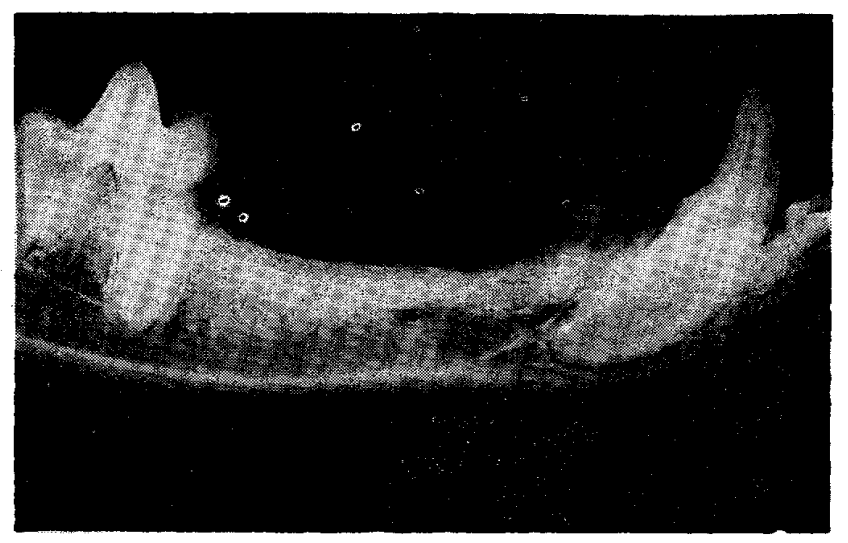

写真23.

2) 病理組織所見

術後 7 日：19号 $\mathbf{L}, 16$ 号 $\mathbf{L}, 24$ 号 $\mathbf{L}, 31$ 号 $\mathbf{R}$
19号 L ; 歯肉粘膜上皮は移植部直上で肥厚がみられ， 上皮乳頭の形，大きさともに不規則である.

粘膜下結合組織に炎症所見がみられるが，とくに母床 の歯槽頂と移植骨との移行部に細胞浸潤が強く，また血 餅もみられる。

母床の下顎管は，その大部分に正常な脂肪骨䯣組織が みられるが，一部で骨創空の底部から穿孔さ机ていて， その部分では，下顎管内一骨片の陌入がみら诚る。この 骨片の周围には，新生肉芽組織の増殖と少量の新生骨梁 の添加がみられ，さらに，その辺縁には造骨細胞が配列 している。

移植骨と母床とはまだ瘉合しておらず，両者の区別は 明瞭である。

新生骨梁の添加は，骨創䑤の底部において母床および 移植骨辺縁から始って括り，また移植骨々䯣内を索状に

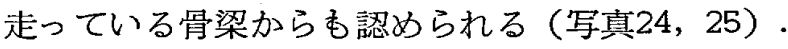

移植骨の下方 $1 / 3$ の部位では，移植骨の周囲执よび内部 （移植骨々髄内）飞新生肉芽組織の増殖がみられる，そ の上方 $2 / 3$ の部位の移植骨々䯣は, 骨䯣本来の構造を保っ ているが，まだ完全に脂肪化されていず，炎症性細胞の 浸潤や出血巣がみら机る。

移植骨の母床より高く形成した部分では，吸収窩がみ られ，また移植骨の周囲に追加移植した局所小骨片の周 囲にあ同じく吸収窩が認められる。しかし，まだ移植骨 は移植時の高さを保っている。

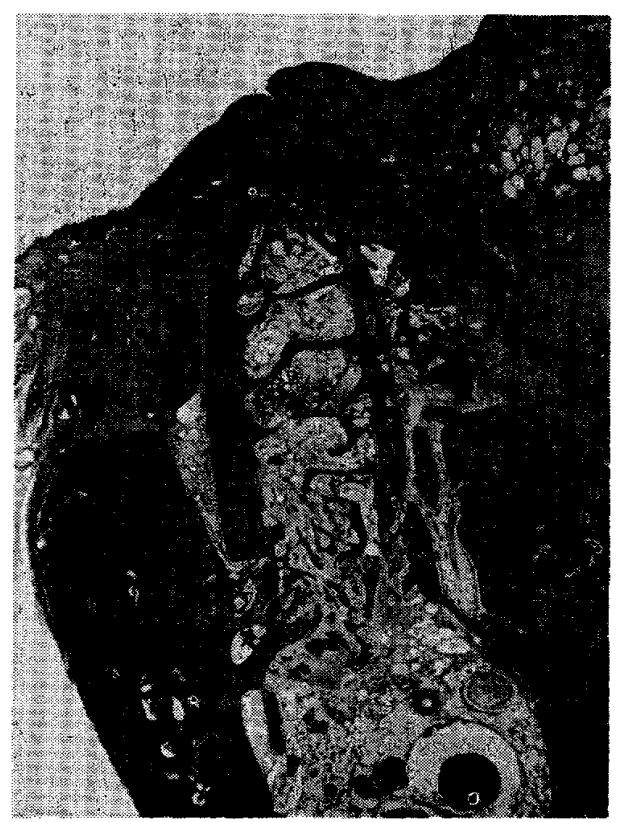

写真24.

16号 L ; 粘膜下結合組織に炎症所見を認めるが，その 範囲は $\mathrm{K}$ 骨移植の場合よりむ狭い。 


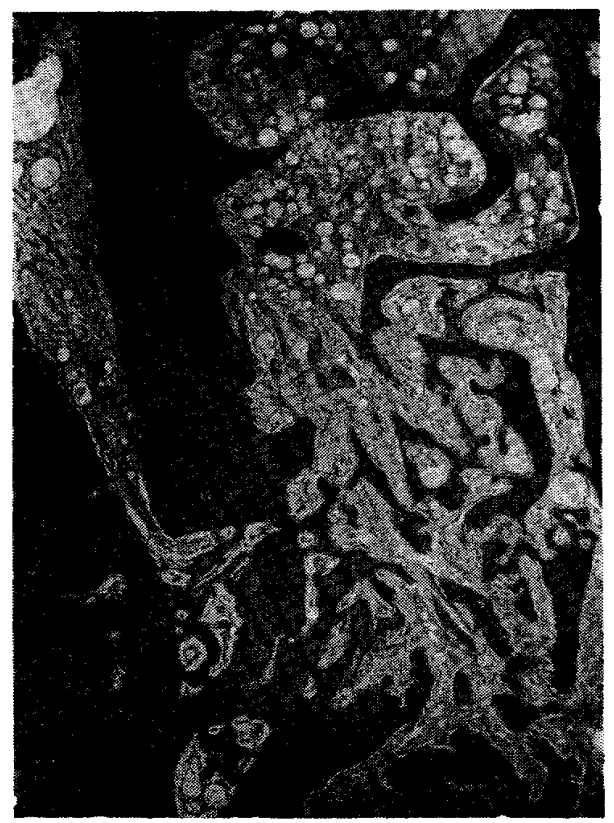

写真25. 写真240拡大

新生骨梁の添加は，骨創腔の底部から側壁の下方 $1 / 3$ ま でにみられる，そてでは，母床抢よび移植骨の両方から 新生骨梁の添加增殖がみられ，一部ではその両者がつな がっている所もあるが，両者の区別は明瞭である．また 骨創整の底部で下顎管へ穿孔している部分では，下顎管 内へ向って新生骨梁の増殖が行わ机ている.

移植骨の下方 $1 / 4$ の部分では, 移植骨々髄内の骨梁から も新生骨梁の添加がみられる。

骨創腔外に高く形成した移植骨の表面には，散在的に 吸収窩がみられるが，19号Lと同じく，いまだ移植時の 高さは保たれている。

24 号 L ; 粘膜下結合組織に炎症性細胞の浸潤がみら れ，また㚘側には出血巣がみられる。

骨創腔底部における下顎管への穿孔部には新生骨梁の 添加がみられ，骨梁間には肉芽組織の増殖がみられる.

骨創㤎内の移植骨の周囲は肉芽 組織で埋められてい て, 新生骨梁の添加は移植骨の下方 $1 / 4$ くらい認められ る.とくに骨創腔の底部では，母床および移植骨両方か ら添加増殖した新生骨梁が一部で連絡している。

移植骨々䯣内においても，下方 $1 / 3$ は肉芽組織で埋めら れていて，その部分では骨䯣内を索状に走っている骨梁 の周囲に，わづかではあるが新生 骨梁の 添加がみられ る. その上方 $2 / 3 の$ 部分では, 炎症性細胞の浸潤が強い が，19号 Lの所見でみられた出血巣は認められない。

骨創脿外に高く形成した部分の移植骨の所見は19号 L の場合とほとんど同様である.

なお，移植骨周囲任追加移植した局 所小骨片の周囲
に，わづかに新生骨梁の添加がみられる所がある.

31号 $\mathbf{R}$ ：歯肉粘膜上皮の肥厚は軽度である. 粘膜下結 合組織にかなり強い炎症性細胞浸潤がみられる。

母床の下顎管は骨創腔と交通しており，その穿孔部に は肉芽組織の增殖がみられ，また穿孔部を中心として， 下䫇管壁に沿って少量の新生骨梁の添加がみられる。

骨創腔内でや>煩側へ傾斜して移植されている移植骨 の周囲は肉芽組織で埋められていて, 底部には出血巣が 認められる.

骨創控の底部では，母床扎よび移植骨から少量の骨新 生が認められるが，母床と移植骨とはまだ癒合していな い.

移植骨々䯣内の上方 $\mathbf{3}$ 《は脂肪骨䯣の状態を保っている が，細胞浸潤がかなり強い。

移植骨の軟組織に接する面には，所々に吸収細胞が散 見されるが，乙れは舌側でより多くみられる．さらに， 移植骨の周囲に追加移植した局所小骨片の周囲でも, 吸 収像が認められる。

なお，母床の㚘頁側霜槽付近に筋組織が認められる。

術後14日：20号L，22号 L，15号 L

20 号 L ; 歯肉粘膜上皮は移植部直上で肥厚しており， 粘膜下結合組織に軽度の炎症所見がみられる。

母床の下顎管壁の骨創腔と相対する部分に, 新生骨梁 の添加がみられる。

骨創腔における新生骨梁の増殖は旺盛で, 骨創腔全体 に及び, さらに母床の䨑槽頂においても新生骨梁の添加 がみられる. そのため, 移植骨は骨創腔内で, 全体的に 母床と結合しているが, まだ両者の区別は出来る（写真 26）・ これらの新生骨梁の添加がみられる部分より上方 の移植骨の辺縁では, 吸収細胞による骨の吸収が進行し ているために，移植骨頂は吸収されてや〉低下している (写真27).

移植骨の下方の部分（骨創空の底部）では, 新生骨梁 の間に骨䯣ができているが，上方の部分の移植骨々髄は 肉芽組織で埋められている.

移植骨々骾内の骨梁にも，新生骨梁の添加打よび造骨 細胞の配列がみられるが, 吸収細胞の出現はほとんどみ られない。

22号 L ; 畨肉粘膜上皮の肥厚は少い，粘膜下結合組織 に打りる炎症細胞の浸潤は，とくに移植骨頂に接する部 分で，かなり強くみられる。

母床の下顎管は骨創腔と交通しており，その穿孔部か ら下顎管内一肉芽組織の増殖がみられ，また下顎管壁の 頬側部分に新生骨梁の添加がみられる. 


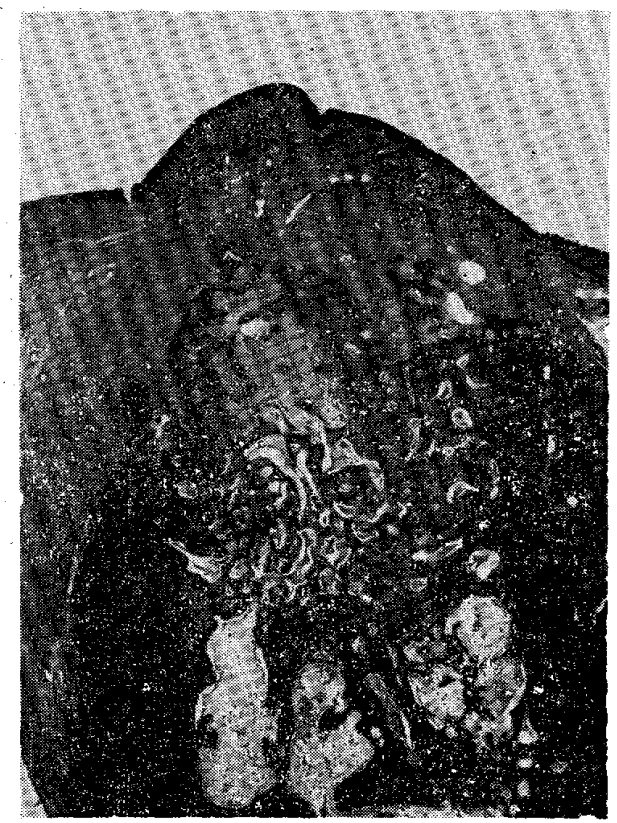

学真26.

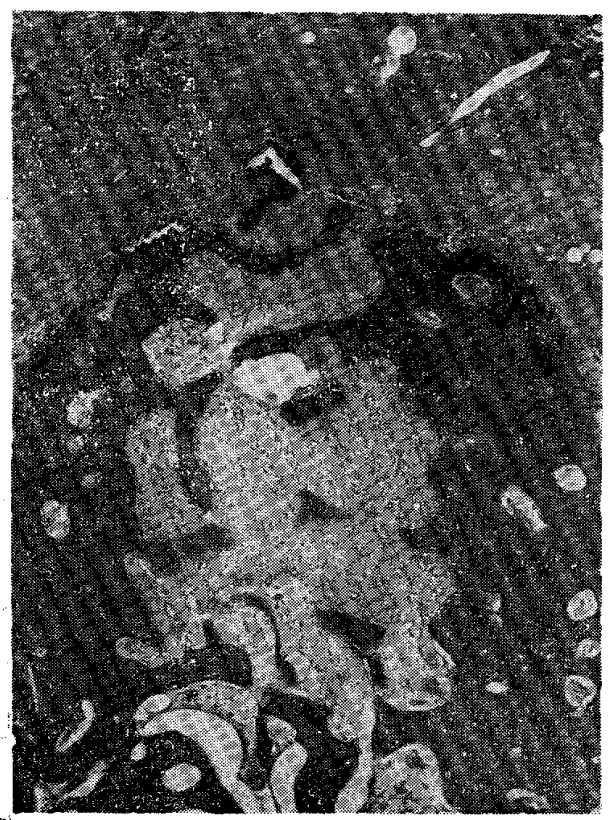

击军真27。写真260広大 ats

移植骨はや>㚘頁側へ傾斜して植立しているために，骨 創嘧の舌側壁と移植骨との間が V字形に離開している.

骨創空内にある部分の移植骨の周囲は肉芽組織でみた されて扔り, 移植骨々䯣内に扎いても, 下方2/3くらいは 买芽組織で埋められている。移植骨々髄の上年 $1 / 3$ では， 炎症細胞の浸潤がかなり強い。

新生骨梁の添加は進行して，骨創腔内では，移植骨お よび母床の両方からの新生骨梁が互に癒合しているが, 两者は明瞭に区別できる。なお，骨創腔の底部では，新 生骨梁の間に骨䯣ができている。
移植骨々髄内に抽いも，下方では新生骨梁の添加が 行われているが，一方では，20号Lではみられなかった 吸収細胞の出現による吸収窩も散見される。

移植骨の母床より高く形成した部分での吸収所見は, とくに移植骨頂部括よび舌側面で強くみられる.

15号L；粘膜下結合組織に拈ける炎症所見は軽度であ 了.

移植骨は㣀植状態が不良で, 頬側へ傾斜している。

骨創空の下方 $1 / 2$ で，新生骨梁によって移植骨と母床 よは結合しているが，まだ両者の区別は明瞭である。そ れより上方では，骨梁の添加があまりみられず，かえっ て移植骨辺縁で吸収が起っていて，この吸収所見は舌側 面の方がより進行している.

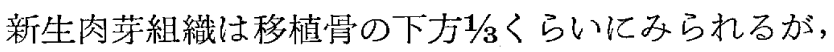
この部位の移植骨の周囲沶よび移植骨々髄内の骨梁に は，造盈細胞の配列がみられる.しかし，一方では移植 骨々髄内の骨梁に散在的に吸収細胞も認められる、移植 骨々髄の上方2/3は壊死飞陷った所之, 線維素網の形成定 みる所お上び細胞浸潤の強い所とが入り混っている.

母床の菌槽頂に扣いても新生管梁の添加がみられ，そ の辺縁には造骨細胞が並んでいる。

術後21日：30号 R, 18号 L, 19号 R, 24号 R

30 号 $\mathrm{R}$; 崡肉粘膜上皮の肥厚がみられ, 上皮乳頭の大 きさ，形態は不規則である．粘膜下結合組織に軽度の炎 症細胞の浸潤がみられる。

母床の下顎管は正常な脂肪 骨髄組 織でみたされてい る.

骨創腔内に添加増殖した新生骨梁は骨創腔全体を埋め て，移植骨と母床とは愈合している．乙の骨創腔の底部 および側壁部に増殖した新生骨梁の間には骨髄組織が出 来つ〉あって, 盈質の改造も進行しているが, まだ移植 骨および母床とは区別できる.また，母床の舌側歯槽頂 にも旺盛な新生骨梁の添加がみられ，その辺縁には造骨 細胞が配列している.しかし, 煩側では造骨細胞の配列 はみられるが，新生骨梁の添加は少い（写真28）.

移植管々髄内では，下方 $2 / 3 は$ 肉芽組織で埋められてい て, その部分の下半分くらいには, 母床加ら添加増殖し た新生骨梁が入りとみ，また同時に移植骨の骨梁からも 新生骨梁の添加が行われている. 残りの上方 $1 / 3$ は肙髄本 来の形態を留めているが，細胞成分が多い。

移植学の骨創腔外に高く形成した部分には，吸収細胞 と吸収窩が散見され，一部では骨䯣に穿孔している所も みられる（写真29）。しかし，移植時の外形および高さ は，いまだはづ保たれている。 


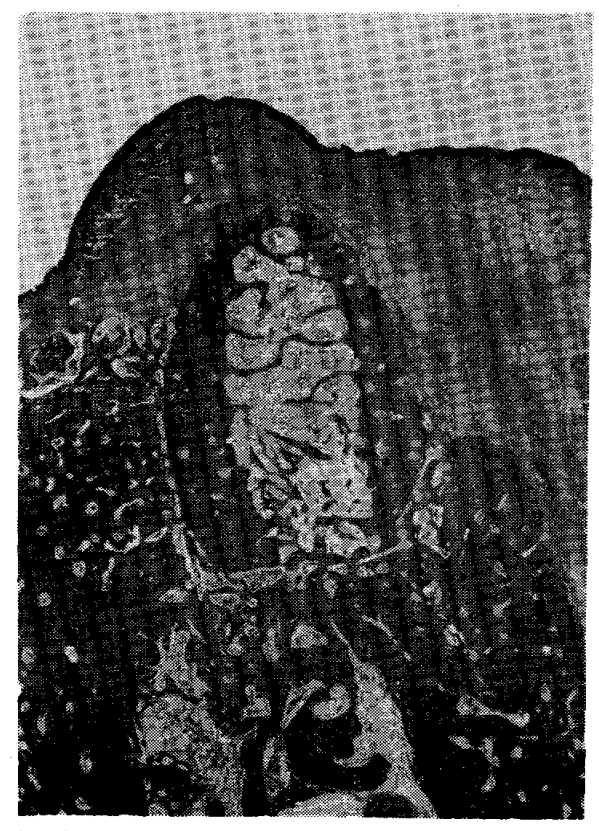

写真28.

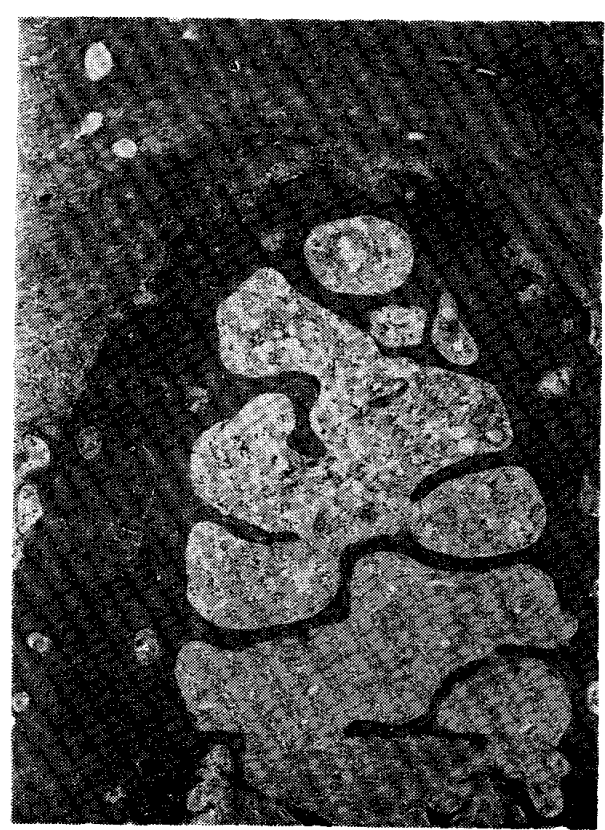

写真29. 写真280拡大

18号 L ; 粘膜下結合組織に炎症所見はほとんどみられ ない。

下顎管は学創空の底部から穿孔されていて, 肉芽組織 が下顎管壁に沿って増殖し，また新生骨梁の添加むみら れる。この穿孔部に添加した新生骨梁の移植骨に面する 側には造骨細胞が並んでいるが，下顎管内に面する辺縁 では吸収がみられる。

骨創腔内に打ける新生骨梁の添加堌殖は進行して，移 植骨は骨創腔内で母床と強く癒合している。また，母床 の歯槽頂に执いても新生骨梁の添加がみられ，乙の新生
骨梁は移植学の力八向って斜め上力に延びて移植骨亡癒 合しているが，その辺縁の造骨細胞の配列は少くなって いる.

新生骨梁の間には骨䯣様の組織が出来ているが，これ は移植骨のかなり上方にまで認められる。移植骨々䯣内 に扣いても骨髄様の組織が出来てきているが，上の方で はまだ肉芽組織の所もある。

移植骨頂では吸収が進行して，かなり強く品んだよう になっていて，軟組織に接する面には吸収窩がみられ る.しかし，全体的にはまだ母床よりは相当高く保たれ ている.

19 号 R；歯肉粘膜上皮は肥厚している。粘膜下結合組 織に炎症細胞の浸潤がみられる。

新生骨梁の増殖によって移植骨は骨創腔内に固定され ているが, 部位によっては, 移植骨と母床とが結合して いない所がある，そこでは，母床からの新生骨梁の添加 はみられるが，移植骨からの骨梁の新生は少く，移植骨 の周囲に，下方の一部を除いてほとんど全般的に吸收が 起っている，また，移植骨骨䯣内の骨梁にも吸収所見が みられるが, 骨梁の新生は進んでいる。

移植骨々髄は，骨創腔の底部に近い一部分のみが等䯣 様の組織になっていて，上力の大部分は肉芽組織で埋め られている。

母床の歯槽頂に扔いても新生骨梁の添加がみられる が，その辺縁では吸収所見も認められる。

移植骨頂でかなり吸収が起っているが，形態的には， な招移植の外形が保たれている。

24 号 R；㐘肉粘膜上皮は肥厚している．粘膜下結合組 織に炎症所見はほとんごみられない。

母休の下顎管と骨創腔とが穿孔した跡がみられるが， すでに新生骨梁によって補填されて隔壁が出来ている.

移植骨は新生骨梁によって母床と癒合している。この 新生骨梁は骨創腔全体に及び，さらに母床の画槽頂にも かなり顕著に認めら扎るが，その辺縁には吸収細胞と吸 収窝が認められる。

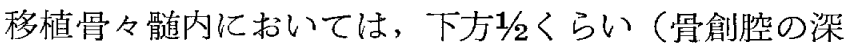
さに相当する）では新生骨梁の添加が著明で，それら新 生骨梁の間の軟組織は骨髄に変りつ〉ある. 残りの上方 1/2の部分では，まだ骨梁の添加は少く，大部分は肉芽組 織で埋められていて，その部分の兴梁の周囲には吸収細 胞が散見される。

骨創腔外に高く形成した部分の移植骨の周囲には，吸 収窩がみられるが，いまだ移植骨は移植時の外形を保っ ている。 
術後30日:29号 R, 18号 R, 22号 R

29 号 $\mathrm{R}$; 歯肉粘膜上皮は肥厚して沶り, 上皮乳頭の大 きさおよざ゙形が不規則である，粘膜下結合組織に炎症所 見はみられない。

母床の下顎管および骨髄は正常である。

移植骨は母床之完全に癒合して，両者の区別はかなり 不明瞭になっている、すなわち，新生骨梁が骨創䐁内の 移植骨の周囲を完全に埋めて, さらに母床の歯槽頂にお いても㕵盛な添加増殖がみられ，特に舌側では斜め上方

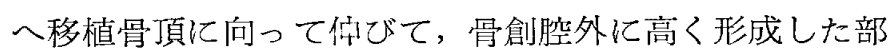
分の移植骨を包みとむような所兒を示しており，また頬 側においても，母床の歯槽頂に追加移植した局所小骨片 の方へ向って増殖している，そして，それら新生骨梁の 辺縁には造骨細胞の配列がみられる（写真30）。

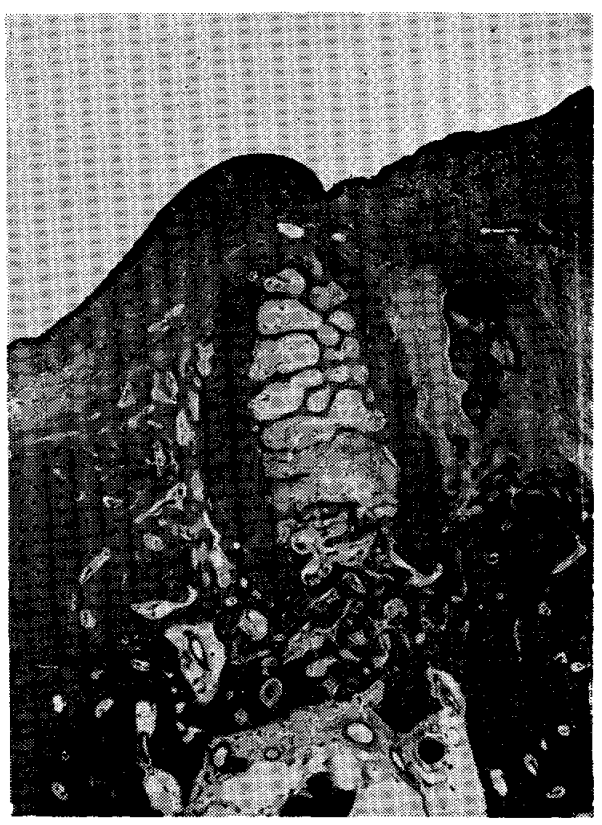

写真30.

新生骨梁の間の軟組織は骨䯣様組織になっており, 骨 創空の底部では管梁の周 团に造骨 細胞が多数みられる がまをな吸収細胞も散見される。

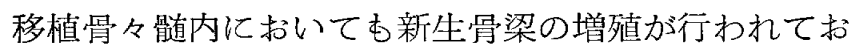
り，その辺縁には造骨細胞の配列がみられる.そして， 骨創然の底部付近では, それら骨梁の間の軟組織に拡張 した血管が認められる。しかし，上方では移植骨々䯣内 を索状に走る骨梁の辺縁では吸収細胞がみられ，一部で は骨梁がほとんど吸収されてしまっている所もみられ る.

移植骨々䯣は, 上方の一部を除いて大部分は肉芽組織 であるが，下の方ほど線維成分が多い，移植骨頂部付近
では吸収細胞之吸収窩がかなり多くみられ, 移植骨は吸 収されてすてし低下している. また，母床の㚘頁側䨑槽頂 の上にみられる局所小骨片の上面にも吸収縕胞が認めら 机る。

18号 $\mathbf{R}$; 歯肉粘膜上皮は肥厚している. 粘膜下結合組 織にかなり強い炎症像がみられる。

移植骨之母床之は新生骨梁によって強固に癒合してお り，一部では両者の区別が不明瞭な所もみられる。ま た，母床の歯槽頂に拉いても新生骨梁の添加がみられる が, その添加量は，29号 $\mathrm{R}$ の場合之反対代舌側よりも㚘 側により多く認められる.

移植骨々髄は，29号 Rの所見と異り，下方 $3 / 4$ には骨䯣

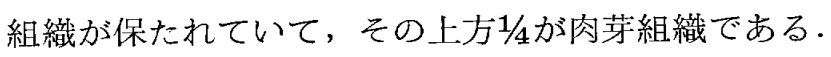

移植骨の骨創腔外に高く形成した部分では吸収が進行 しており，移植骨頂では吸収による骨髄への穿孔がみら れる。

22 号 $\mathrm{R}$; 粘膜下結合組織に炎症所見は認められない。

母床骨, すなわち下顎骨下縁に新生骨梁の添加がみら れ，その新生骨梁の間には骨髄様の組織ができている.

移植骨之母床之は新生骨梁によって癒合しているが， 舌側では，移植骨と骨創腔側壁との間にV字形の隙間が あるために，上方では新生骨梁の添加が遅れている。

新生骨梁の添加は, 母床の曾槽頂に扔いても旺盛で, 移植骨頂の方へ向って伸びている. したがって, 母床の 歯槽頂は移植前よりも高くなっており，ての所見は㚘頁側 でより著明に認められる。

新生骨梁の間の軟組織が骨䯣様の組織に変っている所 見が，骨創腔のほとんど全体にわたってみられる。

移植骨頂扔よびそれに続く新生骨辺縁には吸収窝が散 在している.

術後60日：21号 L，15号 R，20号 R，28号 R

21 号 $\mathbf{L}$; 歯肉粘膜上皮は肥厚している. 粘膜下結合組 織に炎症所見はみられない。

母床の下顎管および骨䯣は正常である.

移植骨は新生骨梁によって母床之完全に癒合している が, わづかに両者の区別はできる.新生骨梁の間の軟組 織は, 上方の一部を除いて, 骨䯣ないし骨䯣様の組織に なっているが，同床の骨随に比心゙ると細胞成分が多い。 移植骨々髄内に氺いても新生骨梁の増殖が進み, 軟組織 の部分は少くなっている.

母床の歯槽頂に添加増殖した新生骨梁は, 移植骨頂の 万人向って伸びて增殖しているために，移植骨は吸収さ れて移植時よりも多少の低下はあるが, 移植前の歯槽頂 の高さよりも高い位置で止っている（写真31）。 
しかも，乙の時期では移植骨辺縁での吸収像はみられ ず，その表面には造骨細胞の配列がみられる。

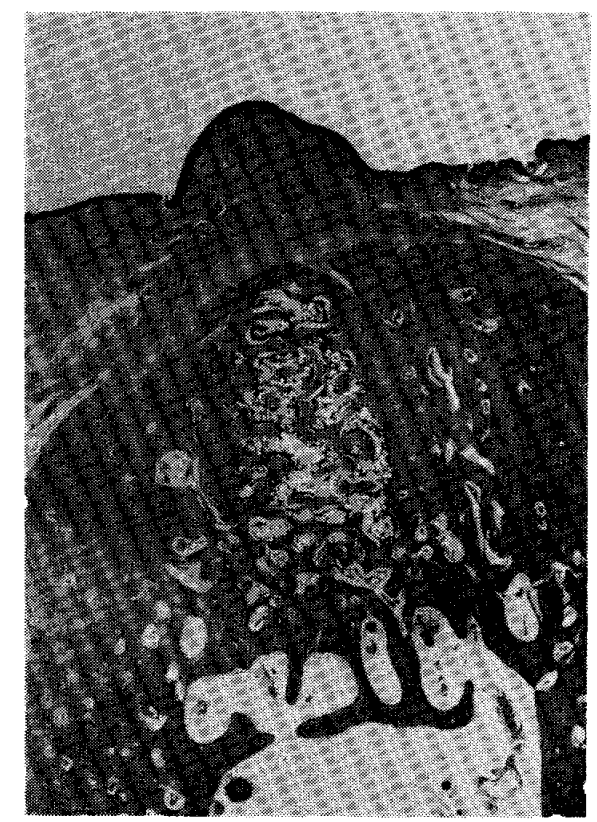

写真31.

15号 $\mathrm{R}$; 雬肉粘膜上皮の肥厚はみられない。峡側で， 粘膜下結合組織に軽度の炎症像がみられる.

移植骨と母床とは，上方の一部を除いて，大体その境 界が不明瞭になっている. 新生骨梁の間には，21号Lと 同様に，骨髄ないし骨髄様の組繊が出来ているが，部位 によっては肉茅組織の所屯若干みられる。乙の新生骨梁 間の骨䯣壁に造骨細胞あるいは吸収細胞がみられる所が ある。

移植䇰頂は吸収されて低下して，一部では陷凹してい る所㫗るが，21号Lと同様に，その败収面には新たに 新生骨梁の添加がみられ，その辺縁には造骨細胞が並ん でいる.しかし母床の頬側歯槽頂で, 粘膜下結合組織に 炎症がみられる部分では，なお吸収像がみられる。

20 号 $\mathbf{R}$; 歯肉粘膜上皮の肥厚はなく, 全体的に, 炎症 所見はみられない。

移植骨と母床との区別は困難である. 新生学梁の間に 出来た骨髄の内壁に吸収細胞をみる所屯ある．との新生 骨内に出来大亮髄は, 脂肪骨髄あるいは骨髄様の組織で あるが，一部では肉芽組織の所もある。

新生骨辺縁には造骨細胞が並九で骨の添加が行われて いるが，所々には吸収細胞す散見できる。

本実験例では，頬側と舌側の歯槽頂の高さはほぶ同一

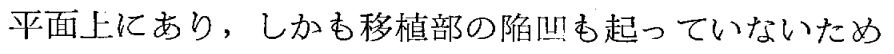
に, 全体的に, 頬舌的な歯槽形態は鞍状を㕵している。

28 号 $\mathrm{R}$ ；歯肉粘膜上皮は肥厚している.
移植骨は母床と完全に癒合しており，両者の区別は困 難である・移植骨々䯣内も新生骨梁で埋められ，それら 新生骨梁の間には, 骨髄ないし骨髄様組織が出来ている が，細胞成分が多い，乙の新生骨梁間に出来た骨䯣壁に は造骨細胞がみられる所が多いが, 部位によっては, 吸 収細胞もみられる。

○＼cjkstart移植骨頂は吸收されて，その高さはかなり低下してい て,な扣かつ，その辺縁には所々に吸収細胞が散見さ れ，他の3例でみられた造骨細胞の配列はほ上んどみら れない。

術後90日：27号 R，13号 L，17号 L，23号 L

27 号 $\mathrm{R}$; 歯肉粘膜上皮は肥厚して扔り，上皮乳頭の大 きさおよび形は不規則である.全般的に炎症所見はみら れない. 㚘頁側に筋組織が認められる。

母床の下顎管ならびに骨䯣は正常である。

移植骨と母床とは完全に癒合していて，全体的に区別 し難いが，歯槽頂附近では区別できる所もある。新生骨 梁の間には骨髄が出来ているが，母床の骨䯣に比べて大 きく，形も不規則である.この骨䯣壁には，造骨細胞が 並んでいるものが多いが, 部位によっては, 吸収細胞が みられる所毛ある。新生骨の骨質毛染色性の強い所之, そうでない所とが入り混っている.

移植骨々䯣は，その下方 $3 / 4$ が脂肪骨髄になっているが 細胞成分が多い，乙の部分では，骨梁の迅縁に造学細胞 の配列がみられる所があるが，吸収細胞はほとんどみら れない. 残りの上方 $1 / 4$ は緻密な肉芽組織で埋められてい て，その部分の骨梁の辺縁には造骨細胞の配列之，また 所々には，吸収細胞も散見される。

母床の歯槽頂には, 㚘賁側乞もに, 移植骨頂の方へ向 って添加增殖した相当な量の新生骨の層がみられる（写 真32）.そてでは部位によっては，その辺縁に吸収細胞 がみられる所すあるが，全体的には吸収所見はほとんど みられない。また，舌側の一部を除いては，造骨細胞も ほとんど認められない。

移植骨頂は，全体的にはほとんど移植時の外形を留め ていて, 相当の高さを保っている.さらに, 軽度の凹凸 がみられる舌側縁では，その辺緣に造骨細胞が認められ るが，吸収細胞はほとんごみられない。

13号 $\mathbf{L}$; 歯肉粘膜上皮はわづかに肥厚している.

母床の下顎管执よび骨䯣は正常である。

移植骨は母床と完全に癒合しているが，両者の区別は 出来る. 新生骨梁中には骨髄が完成している.

移植骨々䯣は脂肪骨䯣になっているが，母床の骨髄に 比べて細胞成分が多い，また移植筲々䯣内の骨梁の周囲 


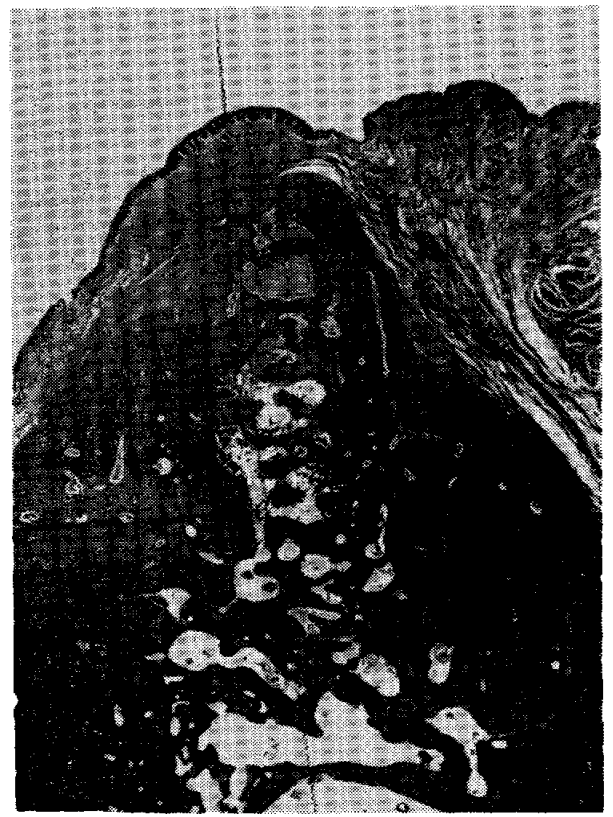

写真32.

に新生骨梁が添加増殖したために移植骨々髄はかなり狭 くなっているが，すでにこの時期では，移植骨々䯣内で の新生骨梁の添加增殖機転はみられない。また，27号 R 之同様に，60日目までは認められた骨髄からの吸収所見 もみられない。

移植骨頂は吸収されて，わづかに母床の㚘側歯槽頂よ りは高いが, 兒側歯槽頂之ほぶ同じ高さにまで低下して しまっている，しかし，すで移植骨辺縁での吸収機軽 は停正していて，功ってその辺縁には新生骨梁の添 加と, 造骨細胞の配列がみられる.

17号 L; 歯肉粘膜上皮は，わづかに肥厚している.

母床の下顎管㧍よび骨髄は正常である。

移植骨と母床との区別は全く不明である．新生骨中に 出来た骨髄は大きさおよび形が不規則で，骨髄壁には， 所々に吸収細胞が散見される．27号 $\mathrm{R}$ 己同様に，移植骨 頂での吸収所見はみられず, かえってその迅縁には造骨 細胞が配列してるが，凹凸が激しい、この新しく形成さ れた歯槽の形態は, 移植骨頂を頂点として, 㚘古的に丸 味を帯びた形をしている.

23号 L；㐘肉粘膜上皮の肥厚は少い。

全体的に移植骨之母床との区別は困難である。

移植骨の下方 $3 / 4$ の部分では，骨梁の間に脂肪骨䯣が完 成している，ただし，その部分の上の方では細胞成分が 多い. 残りの上方 $1 / 4$ の部分では，いまだ緻密な肉芽組織 がみられる部分があり，そこでは骨梁の辺縁に造骨細胞 がみられる。

移植部の歯槽頂は, こまかな凹凸があって, その辺縁 には造骨細胞がみられるが，所によっては，一部に吸犱
細胞がみられる所もある。

術後180日：25号 R，17号 R，21号 R，23号 R 25 号 $\mathbf{R}$ ；蒌肉粘膜上皮は肥厚している.

母床の下顎管および骨䯣は正常である。

新生骨は層板構造を形成して, 周囲の母床骨と全く区 別できない（写真34），移植骨々䯣は細胞成分の多い脂 肪骨髄で，母床の骨䯣に比べて大きい．

移植骨頂は術後90日目に比べて吸収低下しているが, その辺縁は凹凸む少く，骨の添加あるいは吸収所見すす でにみられず，㐘槽頂の煩舌的な形態は，移植骨頂を頂

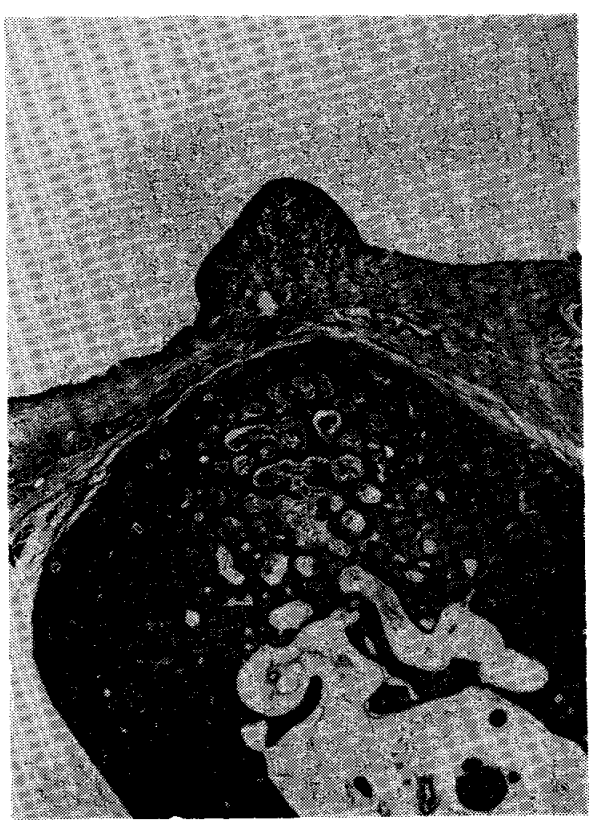

写真33.

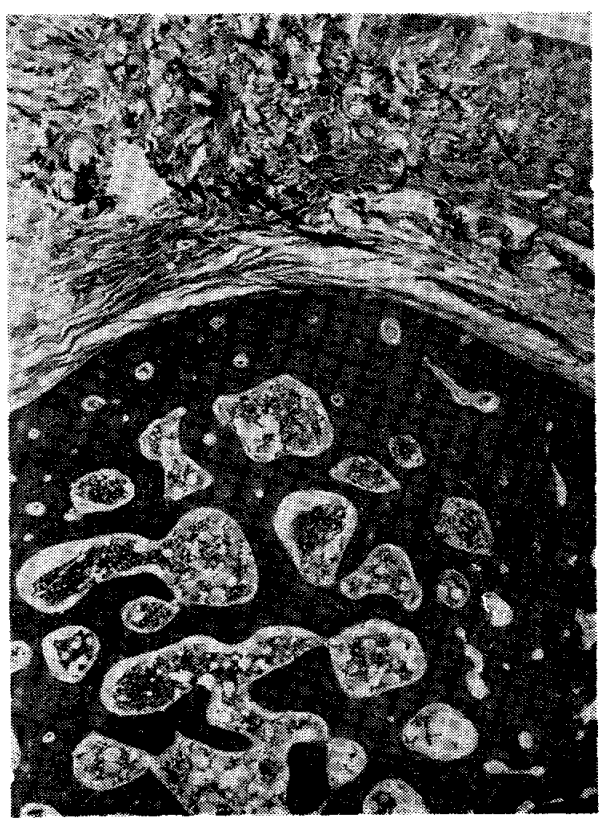

写真34. 写真33の昖大 
点とした鞍状を呈している（写真33）。

17 号 R ; 移植骨之母床との区別は全く不明 瞭である が，移植骨の骨䯣は母床の骨㵦に比べて細胞成分の多い あのが多いものが多くみられる：この移植骨の骨顝壁か らの吸収が少しみられるが，移植部の菌槽頂に招ける吸 収所見は全くみられない。

歯槽頂に㧍りる新生骨の添加層は，いまだ緻密骨にな っていないがてての新しく形成した霜槽頂の煩舌的な形 意は，局部的には凹凸がみられるが，全体的になだらか な丘状を呈している。

21 号 R；移植骨と母:床とは，骨質そのものの区別はで きないが，移植骨の骨䯣は母床の骨䯣より細胞成分が多 く，また移植時と同じょうな形態のものが多い．乙の移 植骨の骨髄壁に吸収所見が少しみられるが, 移植部㐘槽 頂における吸収所見は全くみられない，との新しく形成 した歯槽頂は，乙まかな凹凸があり，いまだ緻密層は形 成されていないが，全体的な歯槽形態は，㚘舌的になだ らかな丘状を呈している。

23号 $\mathbf{R}$; 移植骨と母床との区別は全く出来ないが，他 の3 例之同様, 移植骨の骨䯣は細胞成分の多い脂肪骨䯣 で，母床の骨䯣に比べて大きい，乙の移植骨の骨䯣壁に 吸収細胞がみられる所がある。

移植冎頂は術後90日目に比べて吸收低下して，多少の 凹凸あみられ，そこでは造骨細胞がみられる所ああり， また部位によっては，一部で吸収細胞もみられる。

3) 小括

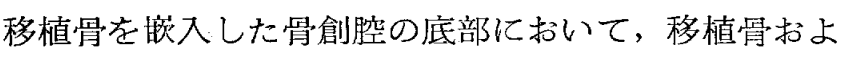
び母床の両者からの新生骨梁の添加が移植後 7 日ですで に始っているが, この時期では, まだ両者は一部で連絡 しているのみである.この新生骨梁の辺縁および移植骨 骨䯣内の骨梁の辺縁には造骨細胞の配列がみられる。し かし, 一方では移植骨の軟組織に接する辺縁, および移 植骨の周团に追加移植した局所小骨片の周囲では, すで に吸収細胞の出現がみられる.

14日目になると, 骨創腔全体にわたって, 新生骨梁に よって移植骨と母床とは結合し, さらに母床の㐘槽頂に おいて屯新生骨梁の添加がみられるようになる.

移植骨頂に打ける吸収屯徐々に進行しているが，いま だ吸収による移植骨頂の低下はあまり認められない，

21日を経過すると, 移植骨は骨創腔内で母:床之強く結 合して, 骨創腔の底部付近では, 新生骨梁の間に骨䯣樣 の組織ができてくるが，まだ同者の区別は明瞭である。

母床の蒾槽頂化打いてもかなりの量の新生骨梁の添加 があるが, 造骨細胞は少くなっており, かえって吸収細
胞がみられるようになる，移植骨頂における吸収も進行 して，I例（18号L）では移植骨頂で陷凹がみられる が，他の 3 例ではまだ形態的な変化は僅少である.

移植後30日目に至ると, 移植骨と母床との癒合はさら に進行して, 骨梁間には骨䯣様の組織ができて, 骨創腔 の底部付近では両者の区別が困難となり, 全体的にもし だいに不明瞭になってくる.

移植骨頂では吸収が進行しており，吸収細胞がかなり 多量に認められる。

さらに60日を経過すると, 移植骨は母床と完全に癒合 して, 両者の区別は1例（21号L）を除いて全く不明膫 になってしまっている。てのことはレ線所見に执いても 同様で，母床之移植骨の境界は全く不明瞭である. 新生 骨梁の間には, 上方の一部を除いて, 全体的に骨䯣ない し骨髄様の組織ができている。

しかし，移植骨の骨創腔外に高く形成した部分では， その辺縁の吸収む進行して, 移植骨頂は少し低下してい て，その辺縁では，なお一部に吸収細胞が散見される が，乙の時期になると，移植骨頂辺縁に造骨細胞の配列 がみられる様になる。

90日目になると，新生骨の骨䯣がほとんど完成する が，母床骨髄に比べて大きさおよび形が不規則である. またその内壁に, 部位によっては吸収細胞（17号L）， あるいは造骨細胞（27号 R）が散見される所がある.移 植骨々䯣も，上方の一部を除いて細胞成分の多い脂肪骨 髄になっている。

移植骨頂の吸収低下は完全に停止していて, 吸収所見 は全く認められず，かえってその辺縁には造骨細胞の配 列之新生骨梁の添加がみられる.レ線所見においても， 移植骨頂は母床の歯槽頂よりむかなり高い位置に認めら れる。

術後 180 日目に至ると, 新生骨にはハーバース氏管と 層板構造がみられるようになり，骨質そのものは母床之 全く区別ができないが，移植骨々䯣は母床の骨髅に比べ て細胞成分の多いものが多くみられる.

移植部䨑槽頂は，局部的には多少の凹凹がみられる が, 全体的には, 㚘頁的な歯槽形態は鞍状ないし丘状を 呈している.

3 対照群

1) V線所見

術後 7 日: 31号 L

母床の歯槽頂に形成した骨創腔が明膫に認められ, 特 記すべき変化はほとんど認められない（写真35）。

術後14日：9号L 


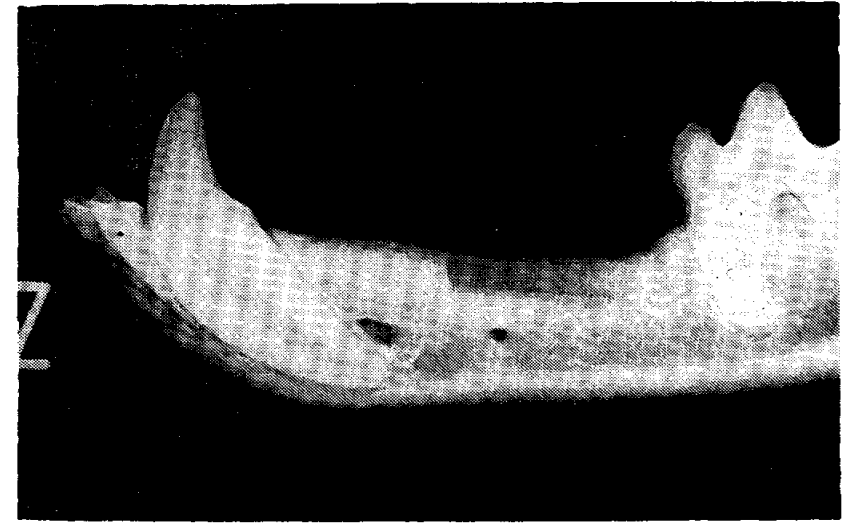

写真35.

骨創腔のレ線透過性がや〉弱くなった程度で，7 日目 の所見と大差はない.

術後21日：30号 L

冝創腔のレ線透過性は低下しているが，その輪郭はま だ判別できる。

術後30日：9号 R，29号 $\mathbf{L}$

骨創腔のレ線透過性はかなり低下して，その輪郭む， 一部を除いて不明瞭になっている（写真36）。

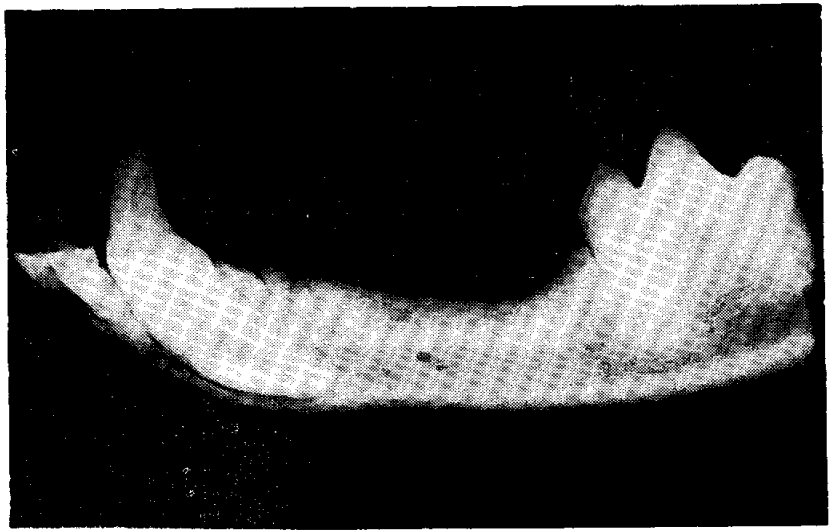

写真36.

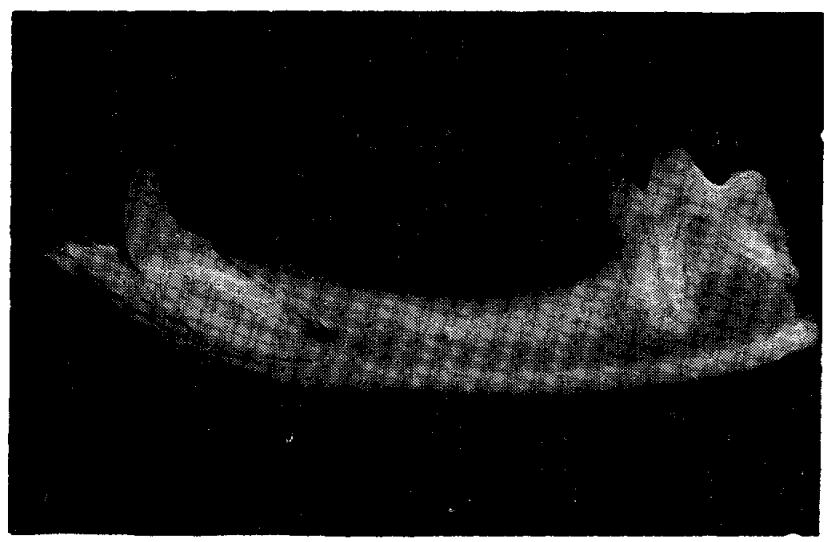

写真37.

術後60日：11号 $\mathrm{L} ， 28$ 号 $\mathrm{L}$

骨創空のレ線透過性はさらに低下し，その輸郭も不明
瞭で，骨質の陰影度は周囲骨加ら自然に移行していて， 骨創腔の大きさがかなり小さくなってみえる（写真37 ）.

術後90日：11号 R, 27号 $\mathrm{L}$

骨創腔はさらに小さくなっていて，最初に形成した時 の深さのて/2くらいになってみえる，骨創腔内のその他の レントゲン的所見は，60日目之大差はない。

術後180日：25号 L

骨創空の部分は，その歯槽頂においてレ線透過性が周 囲母床骨に比べてや〉強い程度で，全体的には判然とし ない，新しい骨梁の紋様がみられる（写真38）。

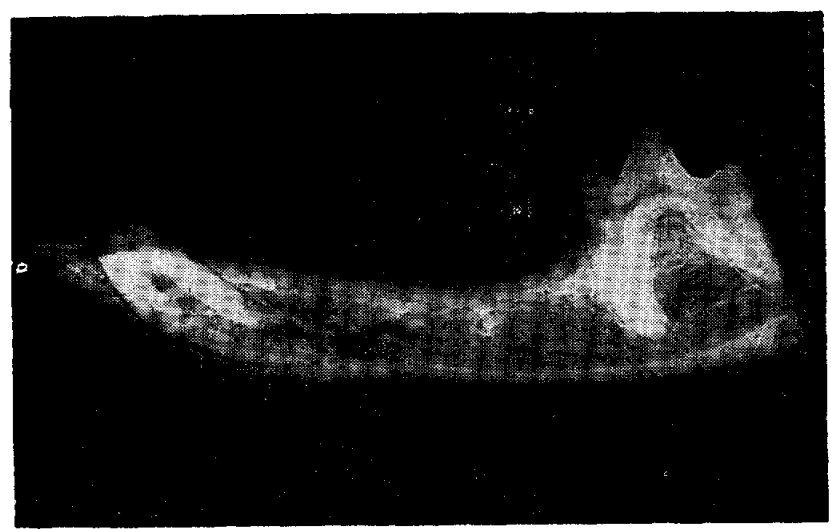

写真38.

\section{2 ) 病理組織所見}

術後 7 日: 31 号 $\mathbf{L}$

歯肉粘膜の肥厚は少い，粘膜下結合組織に炎症細胞の 浸潤がみられ，また出血巣が認められる。

母床の下顎管上骨創腔之が交通している所が認められ る.そこでは, 穿孔部は肉芽組織で埋められており, 母 床からの新生骨梁が添加增殖している。下顎管壁には， 全体にわたって造骨細胞の配列がみられる。

骨創腔内には肉芽組織の增殖がみられ, その辺縁は盃 状を呈していて，その上に出血巣がみら机る.さらに， 盈創腔の底部招よび底部に近い側壁の部分から少量の新 生，骨梁の添加がみられ，その辺縁には造骨細胞が配列し

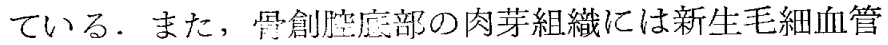
が散在している.

部位によっては，母床の歯槽頂に吸収細胞がみられる 所がある。

術後14日：9号 L

歯肉粘膜上皮に肥厚がみられる。

母床の下顎管は正常である. 歯槽頂に形成した骨創腔 は，本実験例では，移植群に比べてや〉浅い。

骨創腔に执ける新生骨梁の添加はかなり旺盛で，骨創 
腔のシくらいを理めている.そして，てれらの新生骨梁 の辺縁には造骨細胞の配列がみられる．新生骨梁の間は 非常に鬆粗な，血管に富んだ幼若な肉芽組織で埋められ ているが, 移植群とは反対に，下方にある肉芽組織の方 がより若く，新生毛細血管に富んでいる.

一方, 母床の歯槽頂では吸収が行われていて, 歯槽頂 の低下が進行しているととを示している。

術後21日：30号 L

㐘肉粘膜上皮は肥厚している．粘膜下結合組織に炎症 所見はほとんよ゙認められない。

母床の下顎管はお〉む放正常であるが，上壁付近に幼 若な肉芽組織がみられ, 新生毛細血管が散在している. また，その内壁全体に造骨細胞の配列がみられる。

母湫からの新生骨梁は骨創腔のほぐ半分を埋めて, 側 壁では上端にまで及んでいて，さらに母床の歯槽頂にも 少量の新生骨梁の添加が認められる（写真39）。骨創腔 の残りの部分は肉芽組織で埋められているが，ての肉芽 組織は上層部ほよ゙緻密になっている。

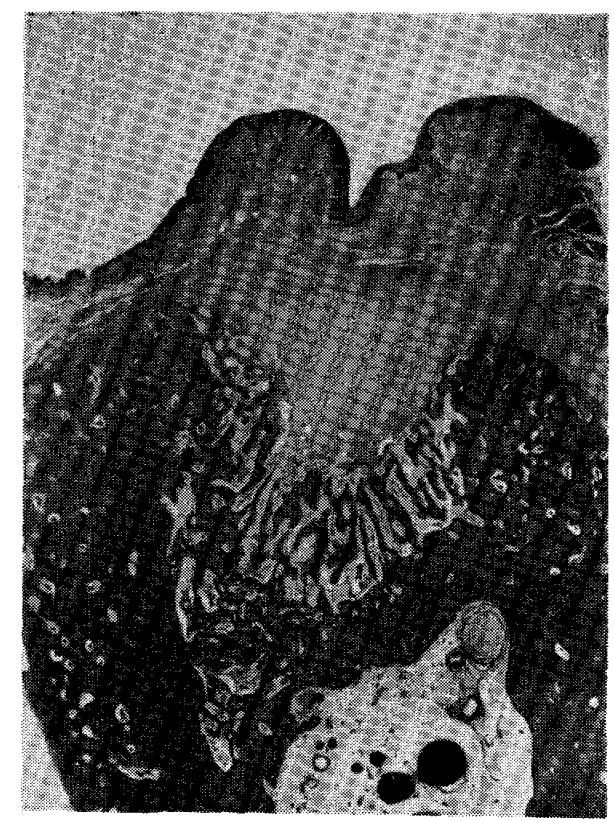

写真39.

新生骨梁の間の軟組織には拡張した血管がみられ，骨 髄様の組織になりつ〉ある。そして，てれらの新生骨梁 の周囲には造骨細胞が配列している.

術後30日：29号 L，9号 R

29 号 L ; 霜肉粘膜上皮は肥厚している．粘膜下結合組 織に炎症所見はみられない。

骨創腔は，その80\%が新生骨梁でみたされているが， 移植群に比べて，その回復は遅い（写真40）。中央部で
は，いまだ陥凹していて，その部分は肉芽組織で埋めら れている．新生骨梁の辺縁には造虫細胞 が配列してい る. 新生骨梁は，へマトキシリンに濃染している石灰化 の強い所と，末熟な所とが多様になっており，母床と新 生骨梁との区別は，骨創腔の底部の一部では不明瞭であ るが，大部分は判別できる、新生骨梁の間の軟組織は， 拡張した血管がみられ，骨髄様の組織になっている。

母林の函槽頂においても少量の新生骨梁の添加がみら れるが，頬舌側ともに，所々に吸収細胞が散在してい る。

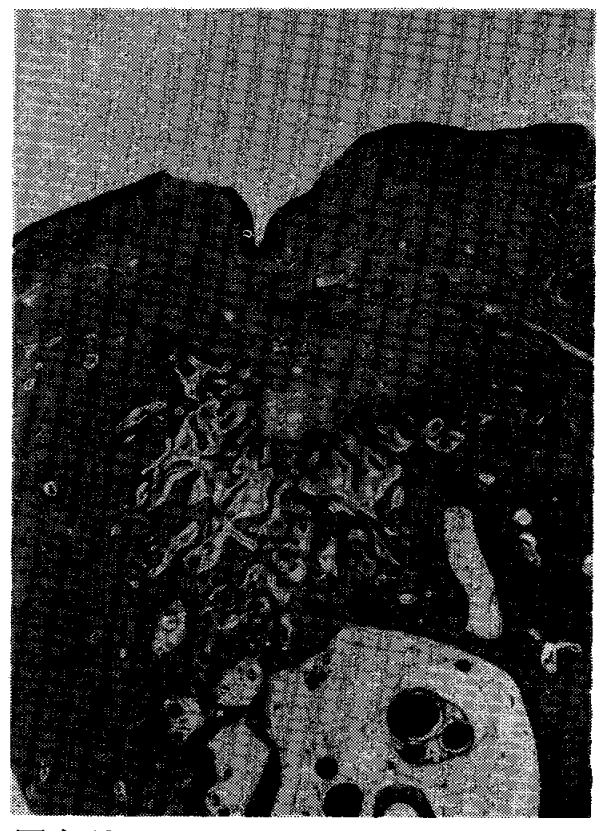

写真 40 .

9 号 $\mathbf{R}$; 移植群に比心゙骨創腔が小さい.

新生骨梁は骨創腔の約2/3を埋めて，さらに増殖を続け ているが， $\mathrm{K}$ 骨移植群より屯，はるかに回復は遅い。乙 の新生骨梁と母床との区別は，学創腔の底部の一部を除 いて，大部分では判別できる。新生骨梁の間を埋める軟 組織は骨䯣㥞の組織になっている。

母床の潾槽頂においては，高位にある舌側歯槽頂では 吸収が進行しているが，反面低位にある㚘側歯槽頂では 新生骨梁の添加がみられる。

術後60日：28号 L, 11号 $\mathbf{L}$

28号 L ; 新生悬梁は骨創䐬の上緣中央の一部を残して 骨創腔内をほぶ埋めつくしており，その辺縁には造骨細 胞が配列している（写真41）。新生骨梁の間の軟組織 は，最上層部を除いて骨䯣になっている．乙の新生骨内 にできた骨髄壁には造骨細胞がみられ，また一部には， 吸収細胞がみられる所もある。

新生骨梁と母休との区別は全般的につけにくいが，新 
生骨ではハーバース氏管, 層板構造がいまだ整っておら ず，また骨髄が母床の骨䯣に比べて大きく，かつその数 屯多い。

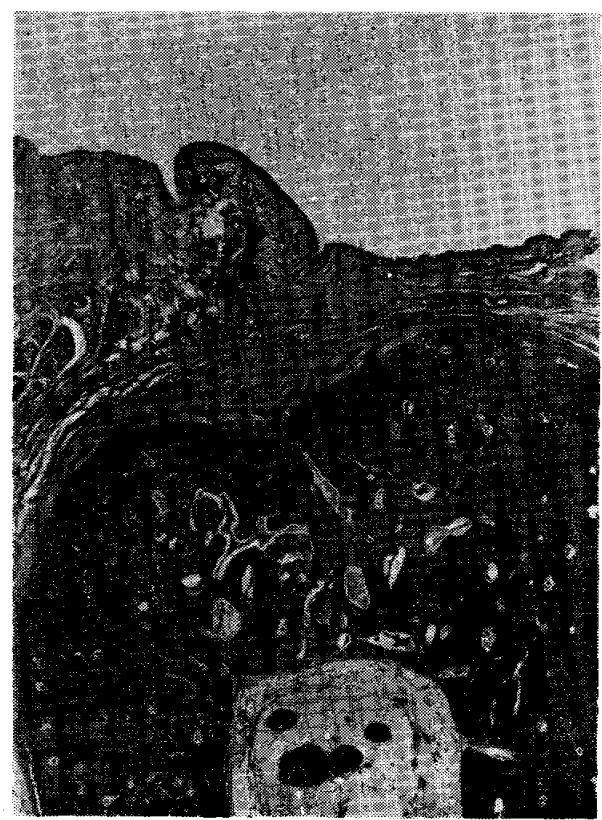

写真41.

几1号 L ; 新生骨梁は骨創腔内のほぶ全体を埋めている が，いまだ中央の一部で，わづかに陌凹がみられる。こ の新生骨は，全般的には母床之の区別は困難であるが， 母床ではハーバース氏管，層板構造が整い，骨髄が少い のに比べて，新生骨では骨梁間にできた骨髄の形，大き さが不規則で，また骨髄になっていない所むみられる。 新生骨内には，所々に吸収細胞が散在している.

新生骨梁辺縁には造骨細胞が並んでいるが，所々には 吸収像屯認められる。

術後90日：27号 $\mathrm{L} ， 11$ 号 $\mathbf{R}$

27号 L；母休の下顎管および骨髄は正常である．

新生骨梁は骨創腔の大部分を埋めているが，いまだ中 央部で, 60 日目之同様の陷凹がみられる(写真42).

母床之新生骨之の境界は不明膫であるが，新生骨内の 骨髄は，母床の骨䯣に比べて大きさ，形が不規 則であ る。

新生骨辺縁には少量の造骨細胞が認められるが，新生 䟫内に吸収細胞をみる所もある。

㚘頁側の蒾槽頂側縁付近に筋組織が認められる.

几1号 R；新生骨梁は骨創腔をとんど埋めて增殖して いるが，その辺縁は，中央に向ってや>凹んだ浅い盃状 を呈して抢り，そのほかの所見も，27号Lと全く同様で ある。

術後180日：25号 L

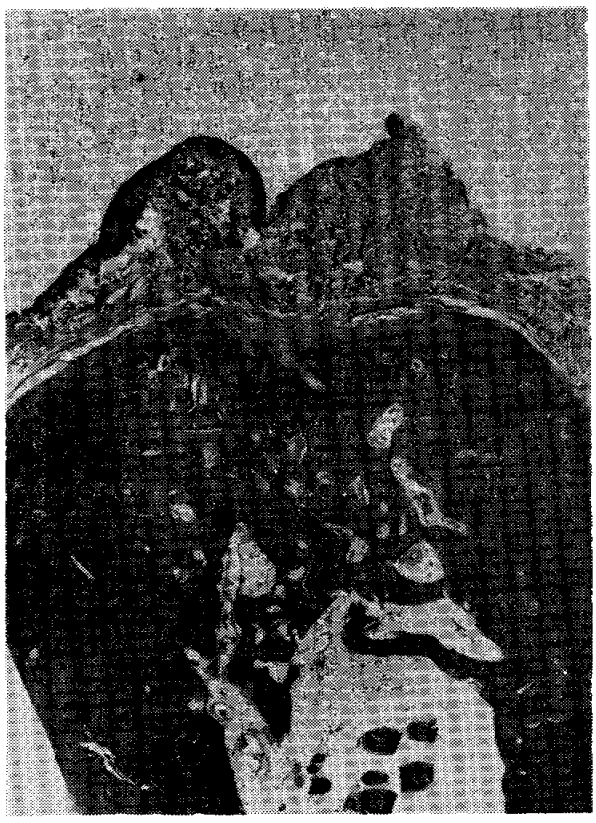

写真 42 .

母床の下顎管は脂肪骨髄でみたされているが，その大 きさは拡大していて, 内部には細く伸びた骨梁が粗い網 状を形成している。

新生骨梁は骨創腔を全く埋めつくして，90日目までに みられた中央部での陥山はすでにみられない（写真43 ) .

母床之新生骨との区別は全く困難で, 新生骨にはハー バース氏管, 層板構造が整い, 最表層部は緻密盈で覆わ れている。

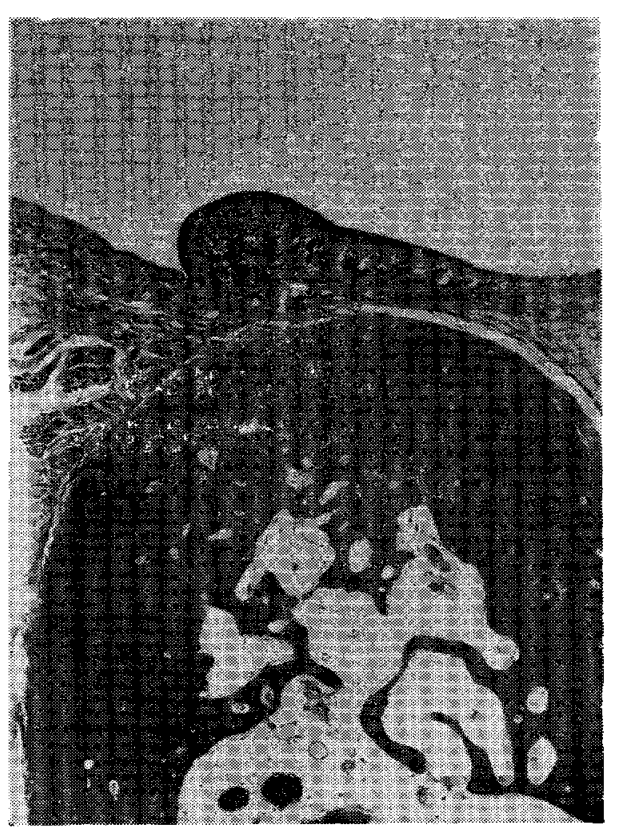

写真43. 


\section{3）小括}

骨創腔内に拈ける新生骨梁の添加は，7日目では底部 においてわづかに認められる程度で, 骨創腔の大部分 は，幼若な肉芽組織と血櫭でみたされている。

14日目になると，新生骨梁の添加はかなり旺盛になっ て，骨創腔の下方为近くまで増殖してくるが，骨創腔辺 縁（母床の函槽頂）には，すでに忣収細胞がみられる.

21日を経過すると，新生骨梁は骨創腔の側壁で，歯槽 頂近くまでみられ，さらに母床の歯槽頂でも少量の新生 骨梁の添加がみられるようになる，新生骨梁の間を埋め る肉芽組織は，移植群とは反対に，上層部ほじ緻密にな ってい.

術後30日では, 新生骨梁は骨創腔の半 分以上を埋め て，その骨梁間には骨髄様の組織ができているが，いま だ母林との区別は明瞭である，そして，60日目に至る と, 新生骨梁は骨創腔の大部分を埋るようになり, かつ その辺緣には，造骨細胞が配列しているが，なお中央部 では陥凹している。この新生骨梁の間には，上層部を除 いて，骨骾ができるいてが，ての骨䯣内には所々に吸収 細胞が散在している。との新生骨と母床との区別はつけ にくくなっている．90日を経逗しても，な接新生骨梁は 骨創腔を完全に埋めず，その辺縁は浅い盃状をなして凹 んでいるが, 少量の造骨細胞が配列している. 新生骨と 母床との区別は困難であるが, 新生 骨内の骨 髄の大き さ，形は不規則で，所によっては，骨䯣壁に吸収細胞が みられるものもある。

術後180日目に至ると, 新生骨は骨創腔を完全に埋め て，電槽頂は平坦になってしまっている，ての新生骨に は，ハーバース氏管，層板構造が整い，母床との区別は 全く不明で，最表層は緻密骨で晋われている.

\section{N 総括ならびに考按}

顎骨，特に下顎骨においては，歯牙のすべてが消失し 無雪顎になると，まず下顎体の約 $2 / 5$ を占める蒾槽部の大 部分が消失して，体上縁はオトガイ孔の值上に位置する ようになる.そして，さらに骨の吸収が骨体に及んだ場 合，その吸収が強い時には，下顎体では顎舌骨筋線まで 吸収してゆく．特に四雬部では根尖と顎舌骨筋線がほぶ 同位置にあるために，顎舌骨筋線が顎堤の内側縁をな し, 斜めに骨外縁に向って傾斜した吸収をする.さらに 吸収が強い場合には，顎舌骨筋線に付着する筋束が菲薄 となり，筋線を越えて下方に吸収が及ぶ場合もある。ま た前函部では, オトガイ隆起部まで吸収下行して, オト ガイ棘が顎堤と同一平面に近くなり，オトガイ孔が靧堤
の上面に位置するようになるのである.

このように，顎堤の高さと顎骨に付着する筋肉の付着 部が同一平面に近くなると，谓下運動そのほかにより義 歯の安定を欠ぐようになる。

以上述べたように，顎骨雨槽部が著明に吸収菱縮した 平坦なもの〉場合には，いわゆる通法に上る義菡製作で は義霜の維持が困難な場合が多い，そこで考えられ，す でに臨床的に応用されているものに，いわゆる implant denture がある.すなわち, 1949年 goldberg と gers hkoff ${ }^{2)}$ は $\mathrm{Co}-\mathrm{Cr}$ 合金である Vitallum の鋳造体を欠 如歯部顎骨粜槽突起骨膜下に植立固定して，乙れを支台 維持装置として義歯を調製したところ, 通常の義歯より 7 倍以上の咀礵機能を有する義歯を完成するに至り，こ れに Vitallium implant denture と命名して発表し た.さらに1950年 goldberg と gershkoff ${ }^{3)}$ はその 遠隔成績を発表, また Berman13)14)，Ogus(15)16)，Lew 9)17)，Newman'15)など相次いで研究成果を挙げ，その後 欧米では盛んに行われるようになった。本邦において も，1957年河合ほか8 は Co-Cr 合金 Biollium を支台 装置とする implant denture を動物ならびに人体に応 用し，咬合咀嚼などの諸運動を営ませて，その経過を観 察して成績を報告，また同じく奬田ほか4す Vitallium の支台装置による implant deuture のI例を報告, 以 来注目を浴びてきた。

このいわゆる implant denture について, 諸家の報 告の中から問題点を拾ってみると，まず骨内莰 植義柬 は, 使用金属がいかに親和性のある合金で, 組織に対し て不活性のものでも, 人工歯根は口腔内と組織とを交通 させているいわゆる半埋入の状態にあるために生物学的 見地から多くの異論があり, 検討を要する多くの問題を 含んでいることは疑いのない事実であって, 現状におい ては, 嵌植された人工歯根は周囲組織の生理的な変化と あいまって, 歯槽骨の吸収という期待に反した現象を発 現してきている，すなうち，㚘貝的な歯槽骨の吸収に上 って人工雨根の動摇が増加し，その動摇によってさらに 周囲組織の変化が増大して著明な動摇を認める場合があ る。懸田6)は，乙の歯槽骨の吸収を㧕制するような生物

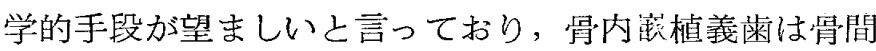
嵌植義菌とटあに成功率が少く，最近ではあまり行わ㧈 ていない，次に，骨膜下赎植義歯は現在行われている力 法の大部分はこの方式による implant denture であっ て，相当良好な成績を挙げている．河合 ${ }^{3)}$ の報告によ机 ば，支台装置が畨槽骨面によく適合し，螺旋などの応用 により固定の完全を期し．しかも歯冠の形態が適当なも 
のは，いづれむ，実験的にも臨床的にも良好で充分使用 に耐えうることを認めているが, 支台装置が骨面に不適 合のあの，あるいは固定不充分で動摇をきたすすの，ま た支台装置の上に作られた崡冠の形態が不良で，外賃性 咬合の認められる場合などはいづれあ結果が不良である 之報告している. 粘膜内嵌植義茵, いわゆる button

denture は, 主として上顎に応用されており，とのあ のは前に挙げた implant denture に比べて施術が簡単 で, しかも維持力も比較的良好であるが, 懸田ほか11)の 報告によれば，ボタンを除去した場合口腔粘膜のボタン

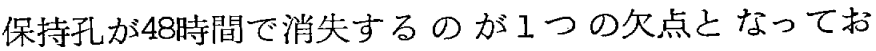
り，またボタン義荬装着後の創傷治癒は，単なる創傷治 癒己異り長期間を要するために, 臨床的には感染の可能 性が考えられ注意を要する.とのことについては，小林 10)装着後最低 3 週間の予後観察が必要であると述べて いる。

最後に，磁石を応用した義歯についてみると，磁石嵌 植義䨤については，眊田20)は歯槽堤の吸収著明な症例に は応用できない久点があり，また機能圧を制禦するのに 充分な磁力が作用すると両磁石の間にはさまれた口腔粘 膜は当然変性を起すことが考えられ，この点でも磁石嵌 植義䨑の欠点が認められると述べている。また，いわゆ る implant denture ではないが，上下䂛総義雪に磁石 を応用して，その反溌力によって義霜の維持を計った報 告をみると，金田ほか211はその問題点について，常に2 床を安定させようとする磁力作用が買安静位にあって, free way space を保っている時にも働いて鄂運動筋に 作用するために，筋の疲労をきたすてとは当然で，て〉 に一大難関が横たわっている．また磁力そのものから考 えて屯，作用反作用の原理から, 反溌力があれば咀嚼運 動時における鄂運動の方向によっては䋅引する力も当然 働くわけで，予期に反した結果が生じてくるあのであ り，臨床上に応用してあ期待した結果が得られなかった 理由むと〉にあると述へてており，そのととを理論的に再 考した実験を行っている。

以上，いわゆる implant denture あるいは magnet denture について諸家の見解を再考してみたが, 結局嵌 植義崡の歴史はまだ浅く，決定的論評を下すわけにはゆ かないようである。

そこで, これらのいわば補緅装置そのものの改良によ って義歯の維持を計る方法に対して, 補綴装置維持の基 礎となる歯槽骨そのものを補緅学の立場から検討した研 究は極めて少い，村田 ${ }^{19)}$ は抜歯後歯槽骨の変化関する 一連の研究の中で, 拔歯後の畨槽骨の吸収を防ぎ，ある
いは吸収された蒾槽骨を形成する目的で，歯槽頂部への

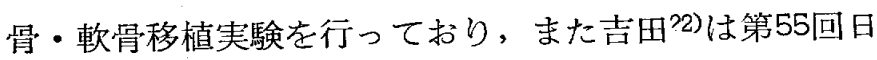
本補経歯科学会で, 骨移植による歯槽形成に関する研究 報告を行ったが，いまだ最終的結論には達していないよ うである。

著者は移植骨として，自家肋骨と，容易に入手できて しかも手術に際して簡単に使用できる点で異種移植骨と しての有用性が証明されているK 骨の 2 種類を選び実験 を行ったのであるが, これら移植群を対照群（非移植群 ）之比較しながら経日的な変化について総括すると, 次 の通りである。

\section{レ線所見の総括 :}

術後 7 日では, 自家肋骨移植群, $\mathrm{K}$ 骨移植群および対 照群ともに骨創腔の輪郭は明瞭で, 移植群では移植骨の 形態执よび骨梁の紋様が明瞭に認められる.すなわち， 骨創腔に関する限りでは，この時期ではレ線学的には3 群とあほとんど変化がみられないようである.とのとと は拔歯窩の場合に打いても同様で，下川40)は抜荬後 7 日 までは窩内の変化はほとんど認められないと述べてい る. 14日目では, 移植群では 2 群ともに, 骨創腔下縁で 移植骨と母床との境界が不明嘹になっている部分も認め られるが, 対照群ではレ線透過性がや〉低下した程度 で，骨創腔の輪郭むまだ明瞭で 7 日目の所見と大差はな い.

21日目になると, 移植群では, 移植骨頂で回』がみら れるようになり骨の吸収が行われていることを示してお り，また骨創腔の底部では移植骨と母床との境界がしだ いに不明瞭になってきて, 新生骨梁の添加による両者の 結合が行われていることが推察される. これに対して， 対照群ではなお骨創腔の輪郭がまだかなり明瞭に区別で きる。

術後30日を経過すると, 移植群では移植骨の辺緣が全 体的にや〉不明膫になって，特に移植骨頂部ではレ線透 過性が強くなって扣り，その部分の骨の吸収を示してい る.しかし，との時期ではまだ移植骨頂は，母床の歯槽 頂よりす高い位置に保たれている。

この移植骨頂に扣ける吸収像に対して，母床の骨創腔 内における移植骨と母床との境界が漠然としていること から, 骨創腔内での新生骨梁の添加が進行していること が推察される.一方, 対照群ではレ線透過性がかなり低 下して骨創控の輪郭も不明瞭になっているが，なお一部 では，まだかなり明瞭に区別できる部分あある。

60日目になると，3群ともに骨創腔の境界が不明膫に なっている．特に移植群では母床と移植骨の陰影度があ 
まり変らず，均質化が進んでいることを示している，し かし， $\mathrm{K}$ 骨移植群では移植骨頂が吸收低下して，母床の 歯槽頂より高く形成した部分が全く消失してみえるのに 対して，自家助骨移植群では，移植骨頂はまだ高く保た れている.一方, 対照群では移植群に比へてて, 骨創空の 部分はなお周囲母床骨の部分よりむレ線透過性が強く暗 影像として認められる. 術後90日を経過して屯, 自家肋 骨移植群では移植骨と母床との判別は困難であるが，な 抢母床の歯槽頂よりも高い位置に移植冎頂が認められ る. K 骨移植群では，60日目の所見之大差は認められな い.これに対して，刘照群では骨創然の部分がかなり縮 少して見えるが，な扮周囲母床骨の部分に比べて暗影度 がはっきりしている。

最終実験期間である術後 180 日目に至ると，移植群で は母床之移植骨の区別が全く困難で，両者の均質化が完 成していることがわかる.しかし，K骨移植群では母床 の歯槽頂より屯高い位置にあった部分のK骨の骨梁は全 くみられないのに対して, 自家肋骨移植群では, 移植部 の歯槽頂が周囲よりもや〉高くなったようにみえる実験 例（23号 R，25号 R） むみられる。一方, 対照群では骨 創腔を形成した部分の歯槽頂付近で，いまだにや>漠然 とした暗影像がみられる。

病理組織所見の総括 :

術後 7 日では, 3 群とも骨創腔を被覆している粘膜下 結合組織に炎症細胞の浸潤がみられ, また骨㓣腔内に出 血巣も認められる，骨創腔壁からの新生骨梁の添加がす でに始っているが, 自家胁骨移植群では, 移植骨からの 骨新生もあるために，骨創腔底部での新生骨梁の増殖は 他の 2 群よりあ旺盛である.また移植群では, 移植骨の 軟組織に接する辺縁に吸収細胞の出現もすでにみられ， 対照群に执いても，骨創空縁（母床の歯槽頂）に吸収所 見がみられる.

14日目になると，3群とすに粘膜下結合組織に㧊ける 炎症所見は全般的に軽度になっているが，実験例によっ ては, 部分的にいまだ強い所むみられる。

新生肯梁の增殖は 7 日目より進行して, 自家肋骨移殖 群では，移植骨は新生骨梁によって母床と結合してお り，また $\mathrm{K}$ 骨移植群でも，母床からの新生骨梁が骨創腔 壁近くのK骨の骨梁を埋めてんでいる，そして，それら 新生骨梁の辺縁には造骨細胞が多数配列している. しか し, 一方では移植骨の辺縁に吸収細胞もみられるが, 移 植骨はいまだ移植時の外形を保っていて, 移植骨頂の低 下はあまり認められない。

また移植骨の骨創腔外に高く形成した部分の煩舌両側
においては，母床の㐘榗頂から新生骨梁の添加が，自家

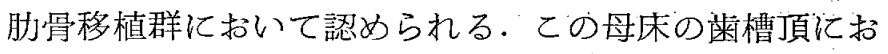
ける新生骨梁の添加は, 高位にある舌側菡槽頂に打いて より旺盛で, その部に追加移植した局所自家骨小片と連 絡しているが，低位にある煩側歯槽頂では骨新生はみら れず, かえって，追加移植した局所自家骨小片の辺縁に は吸収細胞がみられる。

自家肋骨移植群では, 移植骨の下の方の部分では, 新 生骨梁の間の軟組織が骨䯣に变ってきているが，K骨移 植群では, 骨梁の間を埋める部分は非常に幼若な肉芽組 織で, 新生毛細血管と線維芽細胞が豊富にみられる所が 多い。

対照群でも, 新生骨梁の添加は進行して骨創腔内の $1 / 2$ くらいを埋めているが，骨創腔縁では吸収が行われてい る. 骨創脉のそのほかの部分は, 移植群と同様に肉芽組 織で埋められているが，乙の肉芽組織は移植群の場合と は反対に，その下層部が新生毛細血管に富んだ幼若な肉 芽組織であるのに対して, 上層部に比較的古い肉芽組織 がみられる。

術後21日を経過すると, 3 群ともに炎症所見は, 実験 例によって軽度にみられる場合と, 全くみられない場合 とがある。

新生骨梁の添加增殖は自家肋骨移植群が最も進行して 骨創腔全体に及び，移植骨は母床之強く結合して，さら に骨創腔縁の母床の歯槽頂においても新生骨梁の添加が 進行している.すなわち，䫧舌側とも母床の菌槽頂拉よ びその部に追加移植した局所自家骨小片の辺縁に招ける 旺盛な新生骨梁の添加によって両者は新生骨で互に癒合 し,さらに局所自家骨小片の移植骨に相対する面では， 水平方向に骨小片から移植 骨の方へ 新生骨梁が伸展し て，両者は結合している，そして，乙れらの新生骨梁は 全体的に移植骨頂の方へ向って増殖を続けている所見が みられる，婴創腔内においては，新生骨梁の間の軟組織 が骨骾様の組織になっている状態が罥創腔内のかなり上 方にまでみられる.

これに比べて，K骨移植群では学創空の中央部や上層 部では，いまだ肉芽組織中に遊離したま〉のK骨の骨梁 が認められ，しかもその周囲には吸収細胞がみられる。

移植骨の煩舌側縁に捄ける母床の歯槽頂汃らの骨梁の 新生は, 自家肋骨移植群上りあ少いが，舌側ではかなり の量の新生骨がみられた。骨創腔の底部では新生骨梁の 間に骨䯣樣の組織ができて，骨質の石灰化も進行してい るが；埋めこまれたK骨の骨梁は明瞭に区別できる。

対照群であ, 母床からの新生骨梁の增殖によって骨創 
腔の半分以上が埋められており，それら新生骨梁の間の 軟組織は骨髄様の組織に変ってきている. しかし骨創腔 縁（母床の歯槽頂）では, 術後14日目からみられた蒾槽 骨の吸収がこの時期までかなり著明に認められ，母床の 歯槽頂の低下が進行している.

術後30日目になると, 炎症所見は自家胁骨移植群の 1 例を除いて， 3 群ともに認められない。乙の粘膜下結合 組織に炎症所見がみられた自家肋骨移植のI例は, 歯肉 縫合部に执いて術後感梁が実験中にみられたもので, 本 実験の総括所見としては無視してよいと思われる。

骨創腔内に打淁新生骨梁の増殖は, 自家胁骨移植群 できわめて旺盛にみられ, 骨創腔全体に及び, 移植骨は 母床と強く癒合しており, さらに骨創腔外に高く形成し た部分の移植骨の煩舌側縁に沿って，母床の歯槽頂から 移植骨頂の方へ伸びた新生骨梁がみられる。この移植骨

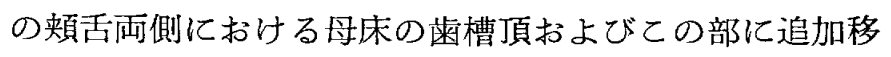
植した局所自家骨小片からの骨梁の新生はきわめて旺盛 で, 相当量の新生骨がいまだ吸収低下の少い移植骨を煩 舌両側から支えるように取り囲み, その辺縁は移植骨頂 に移行している.そして, ての新生骨辺縁には造骨細胞 が配列しているが，乙の所見は舌側の方がより著しい． この時期では, 母床之移植骨との境界が区別できるし， また移植骨の形態から判断しても, 画槽頂の高さは術前 よりかなり高く，また移植骨の㚘頁径は増大している.

骨創腔内で添加増殖した新生骨梁の間には骨䯣様の組 織がみられ，母床と新生骨梁との区別はしだいに不明瞭 になってきている，移植骨々骾内に抢いても，新生骨梁 の添加がみられるが，また吸収細胞による骨梁の吸収も 同時にみられる.

移植骨頂では吸収窩が散在してみられ，移植骨の吸収 が徐々に進行していて移植骨は多少低下しているが，い まだ顕著な形態的変化はみられない。

この自家肋骨移植群に対して, $\mathrm{K}$ 骨移植群では，骨創 腔内での新生骨梁の増植が自家肋骨移植群の場合よりも 劣り, いまだ骨創腔全体を埋めるに至らず, 歯槽頂で近 遠心的な溝状の陥凹を残している. しかし, 新生骨の状 態は自家肋骨移植群と同樣に，骨梁間には骨䯣様の組織 もできており，特に骨創整の底部近くでは正常な骨質に 近い構造を示して，航床との区別が不明瞭になってきて いる.移植したK骨の骨梁は, 新生骨中に埋めこまれた あのでは一部染色性が低下しているものあみられ，また 母床上り高く形成した部分では K 骨の骨梁は軟組織中に ばらばらに散在していて，それらの周团には吸収細胞が みられる.したがって, 移植骨頂は少し低下している。
骨創腔縁（母床の歯槽頂）における新生骨梁の添加む 自家肋骨移植群より少いが, この新生骨の辺縁は骨創腔 内に増殖した新生骨の辺縁に移行している。

対照群における骨創腔内での新生骨梁の添加は K 骨移 植群よりあさらに劣り，骨創腔の約80\%を埋めているに すぎず，したがって，歯槽頂で陷凹がみられる．新生骨 梁の間には, 移植群之同様埧髄様の組織がみられる。

60日目に至ると, 骨創腔 内の新生骨の改造が進行し て, 新生骨と母床との区別が困難になって预り, 新生骨 梁間の軟組織はほとんど骨髄ないし骨䯣様の組織になっ ている。この所見は3群ともにほとんど同様であるが， $\mathrm{K}$ 骨移植群および対照群では，新生骨梁はいまだ骨創腔 全体を埋めるに至らず，歯槽頂で宿凹がみられる．たメ゙ しK骨移植群では骨創腔外にK骨の骨梁が残存している 所むある。これに対して自家肋骨移植群では, 移植骨頂 は吸収低下しているが, まだ母床の歯槽頂よりも高い位 置で止っている. 移植骨の㚘舌側縁における新生骨は, その辺縁が30日目の所見よりもさらに自然に移植骨頂に 移行しているが, 造骨細胞の配列は30日目よりも滅少し ている.また移植骨頂での吸収も進行しているが, 症例 によっては, 少量の造骨細胞の配列と吸収窝が同時にみ られるあのあある.

術後90日を経過すると, 新生骨の改造はさらに進行し て骨髄屯ほ完メ゙成し，母床とは部分的には判別できる所 ああるが, 全般的に両者の区別は困難である.さらに自 家肋骨移植群では, 移植後60日目までにみられた新生骨 の内部に拈ける吸収所見古大体に招いてみられなくな り，全般的に吸収機転は行わ机ていないが，K骨移植群 および対照群では，骨䯣からの吸収所見がいまだにみら れる。

移植部の菌槽頂の状態は, 自家肋骨移植群では移植骨 は吸収されて多少低下し，その辺縁では凹凸がみられる が，乙の時期に至ると移植骨頂における吸収機転はもは やみられず，かえって造骨細胞の配列がみられるように なる. 特に27号 Rでは, 移植部の母床の歯槽頂に扔いて 移植骨を煩舌両側から取り囲んだかなりの量の新生骨の 層が形成されているために, 移植骨の吸収低下は少く, 移植骨は全体的にほとんど移植時の外形を留めて相当の 高さを保っている。しかす，すでに吸収細胞む認められ ない，移植骨々髄も上方の一部を除いて脂肪骨髄になっ ている.

一方 $\mathbf{K}$ 骨移植群では，骨創腔外に高く形成した部分の K骨の骨梁はほとんど消失してしまっている，骨創腔内 を埋めた新生骨の辺縁はいまだに少し陥凹しているが， 
なお造骨細胞の配列はみられ盛んに骨の添加が行われて いる。

てれに対して，対照群では $\mathrm{K}$ 骨移植群と同様に，骨創 腔内を埋めた新生骨の辺縁は浅い盃状をなして陷凹して おり，しかあ造骨細胞の配列は移植群に比べて少い，

最終実験期間である術後 180 日目に至ると，新生骨は 骨創腔を完全に埋めて, ハーバース氏管, 首板構造が整 い，全く正常な骨質を形成しているが，K骨移植群では 新生骨中にいまだ K 骨の骨梁が散在している，自家肋骨 移植群では, 移植骨と母床之は骨質そのものの区別は全 く不明であるが，新生骨々髄は母床の骨䯣に比べて大き く，乙かも細胞成分が多い。移植骨頂は吸収低下してお り，その辺縁は，局部的には多少の凹凸がみられるが， すでに骨の増殖あるいは吸収機転はみられず安定してい て，全体的に㚘舌的な歯槽形態は鞍状をなしている.

以上，移植群および対照群を経日的に比較したが， 3 群ともに骨創腔内での新生骨梁の添加が術後 7 日目です でに認められたことは, 蒾槽骨の削除部に対して新鮮自 家骨小片移植実験を行った Beube (11日目) 23), Linghorn \& $\mathrm{O}^{\prime}$ Connell (12日目) ${ }^{24)}$, 飯田 (7日目) 26), 雨宮 (10日目) 27)などの報告にほメ゙一致している. また移植骨片へ新生骨梁の添加が行われ，一部で母床之 の骨性瘉合がみられる時期は, 霜槽骨削除部への新鮮自 家骨小片移植実験に扔いては， Linghorn \& O'Connel124)は術後16日, 雨宮27) は15日目に，宇治28)は下顎骨に 作製した骨創空への新鮮自家 骨小片移 植で術後 10 日目 に，また Schaffer ${ }^{25)}$ は料牙片（象牙質抽よびセメント 質）移植実験で14日目に認めており，K骨移植実験にお いては，三森29)はウサギの頭頂骨欠損部への移植実験で 7 日目に，川越30)は雬根尖切除創で同じく 7 日目にそれ ぞれ一部で骨性瘉合がみられたと報告した。

著者が行った実験では, 自家肋骨移植群においては, 骨創腔の底部において母床の骨創腔壁からの新生骨梁の 添加とほとんど同時に移植骨から新生添加した骨梁と結 合して，14日目にはすでに下層部で新生骨梁の間に骨䯣 様の組織が出現する. 一方, $\mathrm{K}$ 骨移植群では骨新生の進 行は遅く，またK骨の骨梁はそのほとんどが母床からの 新生骨梁によって埋入されてゆく所見がみられるが，乙 のことは先人の研究之一致しており，K骨自体の骨新生 の誘導力はきわめて弱い上うである.したがって, 新生 骨が骨創腔を完全に埋め盡してしまうのは，本実験では 術後90日を経過してあな打不十分であった。これは自家 肋骨移植の場合には移植骨周囲での新生骨梁の添加が行
われるのに対して，K骨移植では母床からの骨梁の新生 があるだけで，K骨からの骨梁の新生が行われなかった ためである.乙のK骨の骨形成能について, 三森299は穿 頭術法による移植実験で，骨新生は辺縁部骨梁に接する 部分にしか認めず，大部分の $\mathrm{K}$ 骨の骨梁は線維性組織中 に埋まる所見を得ており，巨山31) 抜歯創への骨小片移 植で移植骨を起点とした新生骨の出現は全くみられなか ったと報告した．また原ら32) 臨床例で， $\mathrm{K}$ 骨の骨形成 能を否定している. 本実験においてむ, 全実験例を通じ てK骨を起点とした造骨機転は認められなかった。

自家肋骨移植群之 $\mathbf{K}$ 骨移植群における移植骨の経日的 変化, なかんづく新生骨による置換と. 骨質の改造につ いてみる之, 河村 ${ }^{33}$ は. 自家骨移植の場合は動物にあっ ては，移植後約 2 ケ月をむって骨質の置換を完了し，つ いで機能的骨質の改变の時期に入り，2〜3ケ月で改変 を完了すると，その概要を述へており，高橋34)は拔菌創 で，45日後には随所に骨の改造がみられ，層板骨となっ た部分では旧歯槽骨との境界が不明になると記載してい

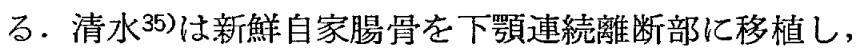
また離断下顎骨の下縁に近い緻密骨のみの再移植を対照 として, 骨改造機転は海綿骨移植では約 2 週以内に始ま り，およそ2 ケ月までに完了し，緻密骨移植では 2 週な いし1ケ月の間に起り：2〜6ケ月の間に完了したと述 べている.一方， $\mathrm{K}$ 骨移植については，川越30は根尖切 除創への移植実験で，300 日後でも移植骨の改造所見は 認められなかったと報告し, 平川ら36)は骨創腔補填の目 的で使用した場合では，I〜4 ケ月を経た頃からその周 縁が徐々に吸収され，これと交替に遅々としてではある が, 新生骨による補填が追従してゆくのを観察したが, 3 年 8 ケ月後のレ線像ですK骨の骨片の存在を確認して いる.また下顎骨連続回復の目的に使用した場合では， 有形片としての $\mathbf{K}$ 骨の外形は1年 5 ケ月のレ線像におい てあいまだ明瞭で，その周囲には骨新生像もなく，骨組 織への改造は遅々として進んでいないことが推定された と述へ，いづれも K 骨の完全な骨組織への改造にはかな りの長年月を要するととが想像され，三森29), 馬渡37), 巨山38)もほぶ同様の結果を得ている.

著者の実験においては，すでに述べたようにK骨移植 では, 術後7日で骨創腔壁からの骨新生像がみられるの は自家肋骨移植の場合とほぶ類似しているが，移植した K 骨の骨梁を中心とした骨新生像は全くみられず，以後 骨創腔壁に近い部分加ら順次母床からの新生骨梁によっ て囲繞されてゆく所見が自家肋骨移植の場合と異ってい た，そして，てれらの早期に新生骨梁によって一旦埋め 
込まれてしまったK骨の骨梁は長期間そのま〉の状態で 新生骨中に残留するのであるが, 術後30日を経過する と, この新生骨中に埋入しているK 骨の骨梁の一部で染 色性の低下しているのがみられるようになり, 羊々とし てではあるが，骨創空壁に近い部分から徐々に改造が行 われることが推察された. しかし，乙れら新生骨中に残 留するK骨の留梁は, 最終実験期間である術後 180 日を 経過しても，いまだ画然と区別され散在して認められ た、また骨侴腔の中央部および上層部にある $\mathrm{K}$ 骨の骨 梁，い〉かえれば骨創腔壁から遠隔部にあるK骨の骨梁 は，母床からの新生骨梁によって埋入されるのが遅れる ため比較的後期まで肉芽組織中に孤立し，しか屯それら の $\mathrm{K}$ 骨,の骨梁の辺縁には吸収細胞が みられるようにな り，日時の経過とともにK 骨の骨梁は散在性になる。し かし術後90日では, 骨創䢁内にあるK骨の骨梁は新生骨 中に埋めこまれてしまう。

自家胁骨移植の場合は，K骨栘植の場合之同様に，術 後 7 日の所見で新生骨梁の添加がみられるが，ての場合 骨創腔壁加らの骨新生之同時に移植骨加らの新生骨梁の 添加が行われて抢り，乙の両者加らの骨梁の新生は当然 $\mathrm{K}$ 骨移植の場合より速かに進行して, 経日的に骨創腔内 を埋めてゆき，さらに移植骨々䯣内においても，骨創腔 の底部骨壁加ら伸展した新生骨梁之, 移植骨々髄内から の骨梁とが互に瘉合して，しだいに移植骨之新生骨之は 境界不鮮明に移行してゆく．ての移植骨々䯣内での新生 骨梁の増殖は徐々に進行してゆき，およそ術後60日で移 植骨々䯣内全体に及び，そ扎ら新生骨梁の間に骨骾ない し骨䯣様の組織ができ, 術後90日で骨創腔内の下方 $3 / 4<$ らいまで脂肪骨髄の所見がみられるようになる.そして 最終実験期間の術後 180 日目には，新生骨中に脂肪骨髄 が完成して正常な歯槽骨とほとんど同じ状態になってし まうのである。

村田 ${ }^{19)}$ は犬の蒾槽頂に新鮮自家腸骨移植を行って, 術 後工年までの観察で, 移植骨は部分的には吸収される が, 大部分は生存して新生骨で㽞換されてしまうことは ないと述べ, 河村の見解己同じ結果を得た。また雨宮 27)，飯田36)なども局所自家骨小片移植で同様の結果を報 告している，著者の実験に扔いては，最終的には移植骨 の骨創腔外飞高く形成した部分は，その大部分が吸収さ れてしまい，また骨創腔内に巍入した部分の移植骨々䯣 内に拀いて部分的には吸収がみられたが，最終実験期 間の術後 180 日目までの観察では, 移植骨のすべてが新 生骨によって置換されてしまうことはなかった。

次に骨創腔外に高く形成した部分について，まず母床
の歯槽頂に抢ける変化についてみると，Beube?3)は犬を 用いて，歯槽骨を約 $6 m m$ 切除し同部に煮沸牛骨粉を移植 して対照群と比較した結果, 移植によって歯槽骨の再生 が促進されたと述べて括り，また Linghorn \& O'Connel1!も同様の実験で新鮮自家骨を移植して, Beude と 同様に歯槽骨の再生を認めた。Schaffer ${ }^{25}$ ) は猿打よび 犬の㐘周組織に軟骨抢よび雪牙小片を移植して，同じく 実験部位に骨新生がみられ，移植片によって骨性治癒が

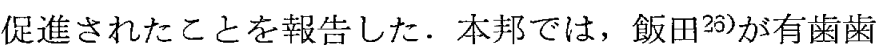
槽骨の削除部に局所自家骨片を移植して，Beube，Linghorn \& O'Connell の所見に一致した広範囲な歯槽骨 の再生を認めたが，㐘槽縁までの骨の再生をみた例はわ づかに2 例であったと報告したが，雨宮27は同様の実験 で術後60日で骨頂は高く，一部には上皮付着より上方に 存在する骨片に新生骨の添加がみられ, 過剩の骨新生が 認められたと報告している。

本実験に扫ける骨創腔縁，すなわ方移植骨の頬舌両側 縁に抢ける母床の菡槽頂加らの新生骨梁の添加の状態 は，まず骨移植を行わなかった対照群では，実験の中期 から後期にかけて軽度の骨新生がみられたが，乙れは初 期に吸収所見が顕著であったことから，骨創臊縁の修正 あるいは補強的役割を果すむのであろうと考えられる。 この所見は, 下川39), 高橋10)の抜歯創窩縁部の治癒経過 に類似している. また歯槽骨切除後の歯槽骨の変化につ いて検索した横溝11), Colling 2) らも歯槽骨の再生を認 めなかったが，乙れらの結果を総合し，また本実験の対 照群の結果す併せて, 有齿々槽, 無蒾々槽に拘らず, 骨 移植を行わなければ歯槽骨の再生は期待できないととを 示している.

これに対して, 骨移植群では移植部の母床の歯槽頂に 扣ける新生骨梁の添加は，対照群に比べて早期から旺盛 に認められる。このととは Boyne \& Lossee'.つ猿の抜 䨑創への無機質骨粉移植実験および高橋34)の新鮮自家骨 小片移植実験に招㳔る拔蒾窩縁の所見に類似している. さらに移植群を詳細に比較検討してみると， $\mathrm{K}$ 骨移植群 では初期から吸収所見が対照群に比べて少く, 術後21日 目になると骨梁の添加がかなり多くみられるようにな り，30日目には骨創腔内に添加増殖した新生骨梁と移行 し，60日目には新生骨の改造が骨創腔の下層部からしだ いに進行して，以後しだいに母床との区別が困離になる が，K骨が異種移植骨であるために新生骨との癒合が遅 く，かつ移植骨頂の吸収低下が早いために，移植部の母 床の歯槽頂での新生骨梁の添加量は自家肋骨移植の場合 よりあ少い, 一力自家肋骨移植群では, 移植部の母床の 
歯槽頂での骨梁の新生が始るのは，K骨移植群より時期 的に早く，術後14日目にはすでに旺盛な添加がみられ， 特に舌側では移植骨の周囲に追加移植した局所自家骨小 片に連絡している．乙の所見は21日目てはさらに進行し て，局所自家骨小片の自家胁骨に相対する面加ら，水平 方向に移植自家肋骨に向って新生骨梁加伸展して，両者 はこの新生骨梁によって瘉合している所見がみられ，こ れらの新生骨は全体的に移植骨頂の方へ斜め上方に伸び ている，そして術後30日では，てれらの所見が最も顕著 に認められ，しかも新生骨梁の辺縁はや〉吸収低下した 移植骨頂と移行的になり，かつその辺縁には造骨細胞が 多量に配列している。この時期ではまだ新生骨と母床と の区別は明瞭で，移植骨の吸収状態からみても移植骨頂 はかなり高く保たれている，しかし術後60日目になる と，新生骨辺縁での造骨細胞はしだいに減少し，しかも 移植骨頂はこの時期まで徐々に吸収低下が進行するので , 下方 (母床側) からの骨梁の新生上, 上方（移植骨頂 ）からの移植骨の吸収とが丁度出合うような状態になっ て，母床の歯槽頂における骨の添加増殖機転はしだいに 停止の方向をたどるのである. そして以トの所見は全実 験例と屯に煩側に比べて舌側の方が優勢であったが，乙 れは飯田26)の実験結果に一致している.

この移植骨の頬舌画側縁の母床の歯槽頂における新生 骨の添加時期は, 前述のように術後14日目からみられる のであるが，乙れは骨移植による歯槽骨の再生夷験を行 つた Linghorn \& O' Connell (術後16日)，雨宮（術 後15日），Schaffer（歯牙片移植で術後14日）の成績 にほぶ一致し, 飯田 (術後21日) の実験粘果より早かっ た。

最後に移植骨自体の母床より高く形成した部分の経日 的変化について考察してみると，3群の比較所見で述べ たように，移植骨は 2 群と屯植移後 7 日目ですでにその 軟組織に接する辺縁において吸収所見がみられ，以後経 日的にほぶ術後60日まで吸収低下が進行する。この移植 骨頂の低下の度合は, 自家肋骨移植群と $\mathrm{K}$ 骨移植群とで は，各時期での進行程度に差がみられた。すなわち，母 林の骨創腔内での骨性治癒の進行状態が, K骨移植群に 比べて自家肋骨移植群の方が遥かに良好で，またすでに 述べたように，移植骨の頬舌両側縁における新生骨梁の 添加増磌が自家肋骨移植群の方が遥かに旺盛であるため に, $\mathrm{K}$ 滑移植群では移植後60日から90日にかけて, 母床 より高く形成した部分の $\mathrm{K}$ 骨の骨梁は母床加らの新生骨 梁による取り込みが間に合わずに，ほとんと消失してし まって，わずかに骨創敉緣に添加した新生骨梁が骨創腔
内の新生骨に移行しているのみであるのに対して，自家 肋骨移植群では, 術後60日ではまだ移植骨頂はかなり高 く保たれており，しかもこの時期では移植骨頂での吸収 所見も滅少していて，その上母床の歯槽頂からの新生骨 梁が相当著明に移植骨頂の方く伸展して移植骨の側縁己 燱合している.そのために移植時よりも移植骨の㚘頁的 厚径は増大している. この所見は術後90日のI例 (27号 R）に执いても顕著にみられ，乙の実験例では移植骨の 吸収は比較的軽度で, 移植骨の形態からみて移植骨頂は 移植時の高さをほとんど保っているものと思われた．

術後90日では, すでに全実験例ともに移植骨頂での吸 収所見はみられず，かえって造骨細胞の配列がみられる ことから, 自家肋骨移植群では, 術後90日目までは歯槽 形成の目的を一応果していると言える.

吉田22)は自家腸骨移植による歯槽形成後の歯槽堤の形 態変化を石亮模型によって計測した結果について，移植 時に $5 \mathrm{~mm}$ 高くなった歯槽頂が術後 3 ケ月目には0.2〜 2 $m m$ 吸収したが，乙の時期では骨吸収は少くなり安定し て, 対照側歯槽頂之同様な吸収状態を示したと報告し た・本奏験では模型による計測は行っていないが，術後 90日までの組織学的所見から類推して，大体において類 似した結果であろうと考える。

しかし術後180日を経過すると，新生骨は改造されて 母床と同様の安定した所見を示して, 移植群特に自家肋 骨移植群では，移植前には平坦であった㐘槽頂の㚘頁舌的 な形態は靶状を示すようになるが，レ線 所見において は，歯槽頂が高まりを示した例は，4 例中 2 例であっ た。

萌出過程にある歯の歯冠を被覆して，歯に機能的作用 が作用しないようにすると，雬周組織の構造の正常な発 達は全く起らないという Eschler ${ }^{14)}$ の実験的研究が報告 されているが, 無䨑顎に対する機能的作用としては義崡 を介しての適刺载の可能性が考えられる。すなわち，一 般的に言われているように, 義䨑は雬の久損を解剖的, 機能的に回復しているのであるから, 顎堤, 崡槽骨に対 して好ましい作用，すなわちその外形ばかりでなく内部 に招ける機能的な構築構造を長く保存する効果を持って いる45)とすれば，本実験の術後 $2 \sim 3$ ケ月の時期に義歯 を装着することによって新しい所見が得られたであろう ことが推察されるわけである。しかるに義雷装着者と非 装着者との顎堤の形態変化を比較して, 装着者の方が吸 収量が多いという Campbell 16) そのほかの報告もあっ て，義歯装着による顎堤の変化には非常に多くの因子が 復雑に関連していることが想像されるのである。本実験 
においては，移植床に対する義歯の影響についての実 験的検索は行わなかったのでこれ以上の詮䒺は避けた w.

歯槽堤の形態掠よび機能に関連して, 補経臨床上重要 なポイントの一つである㐘槽堤㐘肉粘膜について, 本害 験に打ける経日的な変化をみると，まず粘膜上皮は全実 験例を通じてほとんど移植部直上で肥厚がみられたが， 了群間の差扔よび経日的な有意の差異は認められなかっ た.上皮乳頭の形態についてあ同様汇経日的な変化は認 め難い，また粘膜下結合組織は，場所によって多少異る が, 新生肉芽組織と術後14日目くらいまでは明瞭に区別 されるが，以後しだいにその移行部は不明瞭になり，術 後30〜60日でほとんぞ境界不明になってしまう。この粘 膜下結合組織の厚さの経日的な変化については, 計測し ていないので詳細な変化については不明であるが，相対 的な観察に上れば移植群では術後14日目以後や〉薄くな っているようであるが，全体的術後の経日的な変化は 各実験例でそれぞれまちまちであって，経日的な変化を 論ずるに足る根拠は見出せなかった。対照群でも各実験 期間で有意の差は全くみられなかった。したがって歯槽 堤老被覆する歯肉組織の厚さの差は個体差によるもので あろうと考える。

最後に, 術後の炎症所見について総合的に考察する と，歯槽骨削除部への骨小片移植実験を行った Beube 23), Schaffer ${ }^{25)}$, 飯田 ${ }^{26)}$, 雨宮27) らはそれぞれの実験 で, 術後初期には移植片の周囲に炎症性細胞浸潤を認好 たがしだいに消失したと報告しており， Schafferは 炎症性細胞浸潤がしだいに雪肉褰付近に限局することか ら, 移植片による巽物反応でなく, 歯肉囊付近の蒾石, 霜㖃による細菌性反応であろうとの見解を唱えたのに対 して, 雨宮は炎症性変化の強さには移植群と対照群との 間に明瞭な差異を認めていないととから移植片によるも のとは考えず，むしろこの部の手術後の反応であると考 えた. 本実験においては, 移植群では移植骨が軟組織に 接する部分，すなわち移植骨頂部辺縁括よび母床の歯槽 頂部において初期から中等度の炎症が認められ，経日的 にしだいに軽微になってゆき，大体において炎症所見が みられるのは術後21日までら゙ある。乙れは術後20日で炎 症性変化をほとんじ認めていない雨宮の成績に一致して いる.また対照群に扔いて移植群より炎症所見が比較的 軽度であったととは移植片の影響も考えられないととも ないが, 自家肋骨移植群之K骨移植群との間には有意の 差を認め難く, また炎症の消退時期も移植群と対照群之 に大差はなく，本実験比打る炎症所見は雨宮のいう手
術後の反応上考える方が妥当であろう.

\section{V 結 論}

著者は成犬25頭を用いて，その下顎小曰歯部に歯槽骨 の大部分を欠如した柬槽堤を実験的に作成し，その㐘槽 堤に新鮮自家肋骨および $\mathrm{K}$ 骨を移植骨として合計38例の 歯槽形成を行い，また骨移植を行わない合計10例の対照 群を作成して, 各群の経日的変化をレ線学的ならびに病 理組織学的に比較検討して次のような結果を得た.

ᄂ線学的所見

1）母床に形成した骨創腔の輪郭が一部で不明瞭にな り始めるのは移植群では移植後14日目で, 移植婴下縁に 抢いてや〉不明瞭になってくる．対照群では術後21日を 経過しても，まだ骨創腔の輪郭は明瞭である.

2 ) 以後, 経日的に骨創腔の輪郭は下方からしだいに 不明膫になって, 移植群では術後30日で移植骨之母床之 の境界は不明瞭になり，60日を経過する之両者の境界は 自然に移行してみえるようになってしまう。対照群では 術後30日くらいまでは, 移植群に比べて骨創腔の輪郭は かなり明膫であるが，60日を経過すると移植群と同様に 境界は不明膫になり，骨創腔の陰影像は周团母床骨から 移行的になる.

3）骨創腔内に嵌入移植した部分の移植骨の状態は, 自家胁骨移植では移植後90日で周囲母床骨との判別が困 難になる．K骨移植では移植後60日から90日にかけて網 状にみられるK 骨の骨梁の紋様が認めにく〉なるが，ま だ周囲母床骨よりは暗影像としてみられ，全く区別でき なくなるのは.180日を経過してからである。

4) 移植学の骨創腔外に高く形成した部分は移植後 14 日から21日にかけて移植骨頂で凹凸がみられ始め, 吸収 が起っているてとを示している. そしてK 骨移植群で は, 移植後60日を経過すると母床より高く形成した部分 の骨梁は認められなくなるが，自家肋骨移植群では移植 後90日目に至って屯, な打母床上り少し高い位置に移植 骨頂を認める. しかし移植後 180 日を経過すると，高く 形成した部分はかなり低下している。

病理組織学的所見

1）骨創空に怙ける新生骨梁の添加は3 群と屯術後 7 日目ですでに始って拈り, 骨創靕壁から内腔へ向って漸 次骨創腔を埋めて行くが，その経日的な骨新生状態は， 最初骨創腔の底部抢よび側壁の下方から始ってしだいに 上方へ及んで行く。

2) 自家胁骨移植群では, $\mathrm{K}$ 骨移植の場合と異り, 母 床からの新生骨梁の添加之闰時俰移植骨加らの骨梁の新 
生む行われるため, 他の 2 群代比べて骨新生が旺盛で移 植後14日で移植骨と母床とは結合し，30日目には両者は 癒合して，60日目以後は母 床との移行部は不明瞭にな る.

3） $\mathrm{K}$ 骨移植群では，母床の骨創腔壁からの新生骨梁 が付近のK骨の骨梁を埋めこみながらしだいに骨創腔内 を埋めてゆくが，移植後90日を経過してもな捐創腔全 体を埋めるに至らない。

4) 新生骨梁の増殖は早期に执いては自家肋骨移植群 が最も旺盛で, ついで $\mathrm{K}$ 骨移植群, 対照群の順で, 術後 90日まではその差異を認めるが，術後 180 日を経過する

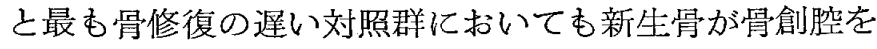
完全に埋めて，しかも骨䯣が完成しハーバース氏管，層 板棈造が整い各群間で顕著な差異が認められなくなる。

5) 骨創腔縁（母床の歯槽頂）では初期においては吸 収所見がみられるが，その後は新生骨梁の添加が起り， 特に自家肋骨移植群では移植骨辺縁の母床の㐘槽頂から 移植骨頂に向って伸びるかなりの量の新生骨梁がみら れ，煩舌両側から移植骨を支えるように增殖している。 この所見は移植後90日までみられる.

6 ）移植部を覆う歯肉粘膜組織の厚さは実験例によっ てまちまちで, 経日的な変化はみられず単に個体差によ るものと思われる。

7) 移植骨は新生骨によって置換改造されて行くが, 移植肾の全部が置換されてしまうことはなく，特にK 骨 の骨梁は移植後 180 口を経過してもなお明瞭に新生骨中 に埋入されたま〉散在して認められる。

8）移植骨の母床より高く形成した部分は，その辺縁 の軟組織に接する面に，すでに移植後 7 日目から吸収細 胞の出現がみられ，以後経日的に吸収が進行して移植学 頂は低下するのであるが， $\mathrm{K}$ 骨移植群では移植後60日か ら90日で母床より高く形成した部分は，一部を除けばそ のほとんどが消失してしまうのに対して，自家肋骨移植 群では移植後60日から90日までは, まだ母床よりかなり 高い位置で移植骨頂の低下は留まっている。

9 ）移植骨頂の吸収低下は移植後90日くらいまでは徐 々に進行するが, 自家肋骨移植群では，乙の時期になる と移植骨頂に求ける吸収は停止してその吸収面には新た に造骨細胞の配列がみられるようになり，術後180日を 経過すると移植部歯槽頂は鞍状を呈し, や〉横径を增し ている.

10）以上の所見を総合して，著者が行った骨移植法に よる歯槽形成は，移植後90日目までは，特に自家肋骨移 植では好結果を示したが, 最終的には鞍状の崡槽頂を形
成するによがまった。

稿を終るに臨み, 終始御指導, 御校閲を賜った平川正 輝教授㧍よび上野正康教授に深甚の謝意を表すととむ に, 御助力を戴いた口腔病理学教室北村勝也講師および 第 1口腔外科学教室巨山保講師ならびに教室員备位に愿 く御礼申し上げます。

\section{V 参 考 文 献}

1.上條淮彦；口腔解剖学 I 骨学，アナトーム社, (1966).

2. Goldberg, N. I. \& Gershkoff, A. ; The implant lower denture: D. Digest, 55, 490, (1949).

3. Goldberg, N. I. \& Gershkoff, A . ; Further report on the full lower implant denture: D. Digest, 56, 478, (1950).

4. 眯田利孝・他; 嵌植義歯（implant denture）の一 例：補緅誌，1，62，(1957).

5. 䀣田利孝・他; 下顎総峐植義歯に招ける保定義歯： 補緅誌， $4 ， 60$, (1960).

6. 懸田利孝・他；骨内嵌植義歯の臨床的観察：補緅 誌, 10, 195, (1966).

7. 懸田利孝-他; 骨内嵌植義蒾の実験的研究（值後嵌 植法について)：補綴誌，12，439，（1968).

8. 河合庄治郎 - 他; implant denture について : 補経 誌, I， 8，(1957).

9. Lew, I. \& Kestenbaum, I. ; An implant button technique for denture prosthesis: D. Digest, 59, 298, (1953).

10. 小林俊三; implant button technique を応用した全 部床義蒾：補緅誌，2，218，(1958).

11. 懸田利孝・他; ボタン義歯に就いて：歯科学報, 58, 329, (1958).

12. 奥野善彦・他; ボタン義歯の創傷治癒に関する実験 的研究：補緅誌，5，53，(1961).

13. Berman, N. ; An implant technique for full lower denture: D. Digest, 57, 438, (1951).

14. Berman, N. ; An physiologic and mechanical aspect of the implant technique and its application to practical cases : D. Digest, 58, 342, (1952).

15. Ogus, W. I. ; Research report on implantation of metals : D. Digest, 57, 58, (1951). 
16. Ogus, W. I. ; Upper implant for an immediate partial denture: D. Digest, 58, 358, (1952).

17. Lew, I. ; implant denture, a simplified upper technique using immediate prothesis : D. Digest, 58, 10, (1952).

18. Newman, C. ; Tissue reaction to Vitallium implantation : J. Pros. Dent. , 4, 850, (1954).

19. 村田睦男; 抜歯後畨槽骨の変化に関する補経学的研 究：口科誌, 14, 204, (1965).

20. 懸田利孝；人工歯 根による 骨内嵌 植義歯：歯界展 望, 27, 641, (1966).

21. 金田重剛・他；義雬に応用する磁力について：補綴 誌， 2，112，(1958).

22. 吉田龍三; 骨移植による歯槽形成に関する実験的研 㚾：補経誌，12，509，(1968).

23. Beube, F. E. ; Factors in the repair of alveolar bone and cementum : Oral Surg., Oral med \& Oral Path, 2 , 379, (1949).

:4. Linghorn, W. J. \& O'Connel, D. C. ; Studies in the regeneration and reattachment of supporting structures of the teeth, I . Soft tissues reattachment : D. Res., 29, 419, (1950), II . Regeneration of alveolar process : D. Res. , 30, 604, (1951).

25. Schaffer, E. M. ; Cementum and dentine implant in a dog and rhesus monkey : J. Periodont. , 28, 125, (1957).

26. 飯田博美 ; 歯槽骨に対する骨移植の実験的研究 : 医 学研究, 29, 293, (1959).

27. 雨宮義弘; 䪽骨歯槽間中隔骨削除部への骨小片移植 に関する実験的研究：口病誌，30，254，(1963).

28. 宇治壽康; 局所自家骨片移植に関する実験的研究 : 口外誌，9，2，(1963).

29. 三森甲子夫; 脱灭骨移植の実験的研究 : 移植, 1 , 204, (1966).

30. 川越 広; 畨根尖切除手術に抬ける Kiel Bone の 応用に関する研究：日大歯学，41，433，(1967).

31. 巨山 保; 抜㥻創への骨小片移植に関する実験的研 究（特に局所骨及び Kiel Bone の検討）：九州雪
会誌， 18, 60， (1964).

32. 原・他; Kiel bone graft の臨床経験(2): 整外誌, 39, 206, (1965).

33. 河村謙二; 骨移植, 医学書院, (1954).

34. 高橋健次郎; 抜歯創の治癒に関する実験的研究特 に抜蒾創への新鮮自家歯槽骨々小片移植の意義につ いて：口病誌，25，126，(1958).

35. 清水博文; 骨移植に関する垁験的研究：口外誌, 14,2, (1968).

36. 平川正輝 - 他; 顎並びに歯槽領域に打ける加工異種 骨の応用に関する研究 : 口外誌, 13，5，(1967).

37. 馬渡和夫; 骨小片移植を応用した歯根端切除手術に 関する研究 : 九州兩会誌, 24，1，(1970).

38. 巨山 保; 骨小片移植による抜歯創の治癒機転に関 する実験的研究：九州㐘会誌，24，371，(1970).

39. 下川敏夫; 抜雪槽の治癒過程に関する知見補遣, 第 I編：久留米医学会誌，16，817，(1953).

40. 高橋庄二郎; 抜歯創治瘉過程のレントゲン的並びに 病理組織学的所見に関する実験的研究：歯科学報, $52,212,265,324,375$, (1952).

41. 横溝一郎; 曾槽膿漏症成因に関する垁験的検討：曾 界展望，11，203，237，274，（1954）.

42. Collings, C. K. ; Experimental production of periodontitis in dogs : J. Periodont. , 28, 7, (1957).

43. Boyne, P. J. \& Losee, F. L. ; The use of anorganic bone implants in oral surgery : $\mathrm{J}$. Oral. Surg. , 16, 53, (1958).

44. Eschler, J. ; Zur Frage der Entwicklung des Paradentiums : J. Stoma. , 37, 134, 202, (1939).

45. 中沢 勇 - 他; 拔歯後の 顎堤の 形態変化：歯界展 望, 33，79，(1969).

46. Campbell, R. C. ; A comparative study of the resorption of the alveolar ridges in denture-wear and non-denture-wear: J. Amer. Dent. Ass., 60,143 , (1960). 